\title{
Evidence of Gas Emissions from Permafrost in the Russian Arctic
}

\author{
Evgeny Chuvilin * $\mathbb{C}$, Valentina Ekimova, Dinara Davletshina, Natalia Sokolova and \\ Boris Bukhanov(10)
}

Center for Hydrocarbon Recovery, Skolkovo Institute of Science and Technology (Skoltech), Skolkovo Innovation Center, 30, Build. 1, Bolshoi Boulevard, 121205 Moscow, Russia; Valentina.Ekimova@skoltech.ru (V.E.); D.Davletshina@skoltech.ru (D.D.); N.Sokolova@skoltech.ru (N.S.); B.Bukhanov@skoltech.ru (B.B.)

* Correspondence: E.Chuvilin@skoltech.ru

Received: 17 August 2020; Accepted: 21 September 2020; Published: 24 September 2020

\begin{abstract}
The active emission of gas (mainly methane) from terrestrial and subsea permafrost in the Russian Arctic has been confirmed by ample evidence. In this paper, a generalization and some systematization of gas manifestations recorded in the Russian Arctic is carried out. The published data on most typical gas emission cases have been summarized in a table and illustrated by a map. The tabulated data include location, signatures, and possible sources of each gas show, with respective references. All events of onshore and shelf gas release are divided into natural and man-caused. and the natural ones are further classified as venting from lakes or explosive emissions in dryland conditions that produce craters on the surface. Among natural gas shows on land, special attention is paid to the emission of natural gas from Arctic lakes, as well as gas emissions with craters formation. In addition, a description of the observed man-caused gas manifestations associated with the drilling of geotechnical and production wells in the Arctic region is given. The reported evidence demonstrates the effect of permafrost degradation on gas release, especially in oil and gas fields.
\end{abstract}

Keywords: gas hydrates; methane emission; gas venting; Arctic lakes; crater; drilling; permafrost; permafrost degradation; intrapermafrost gas; deep gas; gas seep; Russian Arctic; Arctic shelf

\section{Introduction}

The significant increase in atmospheric greenhouse gases, especially methane, in the Arctic regions is among the major causes of climate change and related environmental risks [1,2]. Warming in the Arctic induces degradation of permafrost and the ensuing dissociation of intra- and subpermafrost gas hydrates that maintain voluminous methane fluxes to the atmosphere [1-6]. Most natural methane emission occurs in water-logged depressed landforms, such as dried thaw lakes locally called khasyreys, or poorly flowing river arms and thermokarst sinkholes turned into lakes and swamps, etc. [7-10]. Active gas emission from the Arctic permafrost was observed during gas surveys of the near-surface atmosphere $[8,11]$, the active layer, and water bodies [10,12-19]. Crater features on the surface record explosive emission of deep methane [20-26].

The evidence of more or less intense gas release reported since the onset of petroleum exploration includes ejection of cuttings and mud, and even expulsion of drilling tools, from boreholes, drilling fluid degassing, etc. [27-34]. Gas shows of this kind were observed in northern West Siberia, Taymyr Peninsula, northern Yakutia, and northern Chukchi Peninsula.

Gas releases from both terrestrial and subsea permafrost, and numerous cases have been observed in the Arctic shelf for two recent decades. They are gas seeps and pockmarks found in the Barents and Kara Seas, nonpoint methane emissions in the Laptev and East Siberian Seas, local methane plumes in the East Siberian Sea, as well as gas blows while sampling from bottom sediments. Gas venting 
from shelf sediments has been attributed to the dissociation of gas hydrates in paleopermafrost [35-38]. The relation of methane venting from bottom sediments with gas hydrates on the Russian Arctic shelf has received no direct proof though, in the absence of test boreholes [39,40], but it was recently reported regarding the continental slope of the Russian Arctic in Chukchi Sea [41], and from other Arctic areas (Spitsbergen, Beaufort Sea, etc.) [42,43].

We are undertaking inventory and synthesis of the available ample published evidence on methane emission cases in the Russian Arctic to provide a basis for the discovery of potentially dangerous zones of natural and man-induced gas emission, prediction of the hazard, and assessment of the environmental risks.

\section{Gas Emissions in the Russian Arctic}

Purposeful studies of gas emissions in the Russian Arctic began about 60 years ago when the Urengoy (1966), Yamburg (1969), Bovanenkovo (1971), and other large gas fields were discovered in northern West Siberia. Many exploration and development people engaged in building infrastructure facilities and roads, drilling, and laying pipelines witnessed gas release from shallow monolith permafrost. It was the spontaneous blowout or prolonged release of combustible gas from geotechnical boreholes, or natural emission from Arctic Seas and lakes, which attracted the attention of geoscientists.

The reported cases can be conventionally divided into emissions from terrestrial and subsea (shelf) permafrost according to the place and into natural and anthropogenic according to the origin. Natural gas release on the land often occurs in river valleys, lakes, or swamps, or leaves traces as craters discovered in recent decades during exploration in the West Siberian Arctic.

Having reviewed the available relevant publications, we compiled a table showing the location, signatures, and possible gas sources for major known cases of gas release (Table 1) and illustrated it with a map of gas emission sites in the Russian Arctic (Figure 1). Note that gas generation in the active layer is beyond the consideration in this study. 
Table 1. Known gas emission sites in the Russian Arctic.

\begin{tabular}{|c|c|c|c|c|c|c|c|}
\hline & & No. in Map & Type & Location & Signatures & Possible Gas Sources & Reference \\
\hline \multirow{19}{*}{ 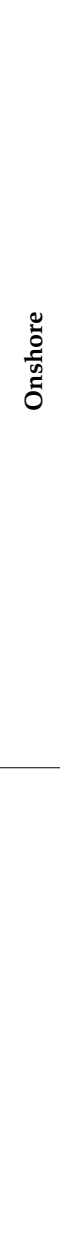 } & \multirow{10}{*}{  } & 1 & \multirow{5}{*}{ 岂 } & Yamal Peninsula, Lake Neyto & $\begin{array}{l}\text { Gas plumes on water surface, mudflows, holes } \\
\text { in ice }\end{array}$ & Deep gas from Neyto field & [10] \\
\hline & & 2 & & Yamal Peninsula, Crater Lake & Craters and parapets on lake bottom, mudflows & Possibly, deep gas-water fluids & {$[10,44]$} \\
\hline & & 3 & & $\begin{array}{l}\text { Yamal Peninsula, group of lakes south of } \\
\text { Bovanenkovo field }\end{array}$ & Blue water, holes in ice, mudflows & Active emission, possibly, deep gas & [9] \\
\hline & & 4 & & $\begin{array}{l}\text { Gydan Peninsula, a lake } 4 \mathrm{~km} \text { from Merkuto } \\
\text { lake on the left bank of Yuribey River }\end{array}$ & A crater encircled by a parapet & Prolonged ascending flow, possibly, deep gas & [9] \\
\hline & & 5 & & $\begin{array}{l}\text { Yamal Peninsula, } 54 \text { km northeast of Arctic field, } \\
\text { Otkrytie Lake }\end{array}$ & $\begin{array}{l}\text { Large craters (up to } 40 \mathrm{~m} \text { in diameter on } \\
\text { lake bottom) }\end{array}$ & $\begin{array}{l}\text { Deep gas, possibly, from Cenomanian } \\
\text { gas reservoirs }\end{array}$ & [45] \\
\hline & & 6 & \multirow{4}{*}{ 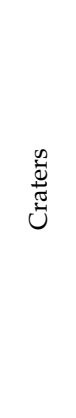 } & $\begin{array}{l}\text { Yamal Peninsula, } 30 \mathrm{~km} \text { south of } \\
\text { Bovanenkovo field }\end{array}$ & $\begin{array}{l}\text { A large crater (up to } 40 \mathrm{~m} \text { in diameter and } \sim 70 \mathrm{~m} \\
\text { deep), encircled with a well-pronounced } \\
\text { parapet; ground dispersed to a distance of } 120 \mathrm{~m}\end{array}$ & Possibly, intrapermafrost gas & {$[22,44,46-49]$} \\
\hline & & 7 & & $\begin{array}{l}\text { Gydan Peninsula, } 100 \mathrm{~km} \text { northwest of } \\
\text { Antipayuta Village }\end{array}$ & $\begin{array}{l}\text { A crater, } 10-13 \mathrm{~m} \text { in diameter and } \sim 15 \mathrm{~m} \text { deep; } \\
\text { no parapet }\end{array}$ & Possibly, intrapermafrost gas & [50] \\
\hline & & 8 & & $\begin{array}{l}\text { Yamal Peninsula, floodplain of } \\
\text { Erkuta-Yakha River }\end{array}$ & $\begin{array}{l}\text { A crater, } 10-12 \mathrm{~m} \text { in diameter and } \sim 20 \mathrm{~m} \text { deep, } \\
\text { with a preserved fragment of a } 2-3 \mathrm{~m} \text { high } \\
\text { mound and ground dispersed to a distance of } \\
100 \mathrm{~m}\end{array}$ & Biogenic gas in a talik and deep gas & [26] \\
\hline & & 9 & & $\begin{array}{c}\text { Yamal Peninsula, } 33 \mathrm{~km} \text { northwest of Seyakha, } \\
\text { Myudriyakha River }\end{array}$ & $\begin{array}{l}\text { Fire gas explosion that produced a } 50 \mathrm{~m} \text { deep } 50 \\
\times 70 \mathrm{~m} \text { crater in a river, with dispersed blocks of } \\
\text { permafrost and ice-rich soil, up to } 150 \mathrm{~m}^{3}\end{array}$ & Possibly, deep gas & {$[24,45]$} \\
\hline & & 10 & & $\begin{array}{l}\text { Gydan Peninsula, north of Deryabino field, bank } \\
\text { of Mongoche River }\end{array}$ & $\begin{array}{l}\text { Fire gas explosion that produced a } 20 \mathrm{~m} \text { deep } \\
\text { crater, with dispersed large fragments of rock }\end{array}$ & Possibly, deep gas & {$[9,25]$} \\
\hline & \multirow{9}{*}{ 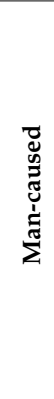 } & 11 & \multirow{9}{*}{ 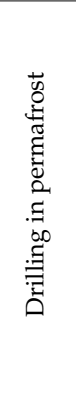 } & North Yakutia, Anabar-Khatanga interfluve & Gas shows at depths of $70-120 \mathrm{~m}$ & Intrapermafrost gas & [51] \\
\hline & & 12 & & Yamal Peninsula, Yuribey River & Gas shows at depths of $10-50 \mathrm{~m}$ & Intrapermafrost gas & {$[52,53]$} \\
\hline & & 13 & & Taz Peninsula, Zapolyarny field & Gas shows at depths of $50-120 \mathrm{~m}$ & Intrapermafrost gas, possibly relict gas hydrates & [30] \\
\hline & & 14 & & Taz Peninsula, Yamburg field & Gas shows at depths of $45-55 \mathrm{~m}$ & Intrapermafrost gas, possibly relict gas hydrates & {$[30,54]$} \\
\hline & & 15 & & Yamal Peninsula, Kharasavey field & Gas shows at depths of $10-210 \mathrm{~m}$ & Intrapermafrost gas, possibly relict gas hydrates & {$[55,56]$} \\
\hline & & 16 & & Yamal Peninsula, South-Tambey field & Gas shows at depths of $40-60 \mathrm{~m}$ & Intrapermafrost gas, possibly relict gas hydrates & [57] \\
\hline & & 17 & & Gydan Peninsula, Pelyatka field & Gas shows at depths of $20-30 \mathrm{~m}$ & Intrapermafrost gas & [30] \\
\hline & & 18 & & Gydan Peninsula, Salman (Utrenneye) field & Gas shows at depths of $50-150 \mathrm{~m}$ & Intrapermafrost gas, possibly relict gas hydrates & [33] \\
\hline & & 19 & & Yamal Peninsula, Bovanenkovo field & Gas shows at depths of $20-130 \mathrm{~m}$ & Intrapermafrost gas, possibly relict gas hydrates & {$[28,56,58-60]$} \\
\hline
\end{tabular}


Table 1. Cont.

\begin{tabular}{|c|c|c|c|c|c|c|c|}
\hline & & No. in Map & Type & Location & Signatures & Possible Gas Sources & Reference \\
\hline \multirow{17}{*}{ 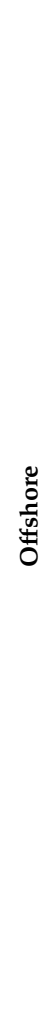 } & \multirow{10}{*}{$\underset{\frac{\pi}{\pi}}{\bar{Z}}$} & 20 & \multirow{10}{*}{ 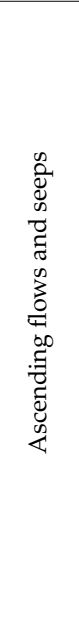 } & Laptev Sea, Yana Delta & Ebullition & Deep gas & {$[30,61]$} \\
\hline & & 21 & & East Siberian Sea, Bennett Island & Gas plumes, up to $1000 \mathrm{~km}$ long & Possibly, deep gas & {$[61,62]$} \\
\hline & & 22 & & $\begin{array}{l}\text { Laptev Sea, between Semyonovsky Island and } \\
\text { Lena Delta }\end{array}$ & Gas seeps & Possibly, deep gas & [63] \\
\hline & & 23 & & Laptev Sea, Ivashkina Lagoon & $\begin{array}{c}\text { About } 20 \text { gas seeps; high concentration of } \\
\text { methane in air }\end{array}$ & Deep gas & [64-66] \\
\hline & & 24 & & Laptev Sea, Kotelny Island & Gas seeps & Possibly, deep gas & [67] \\
\hline & & 25 & & Laptev Sea shelf, New Siberian Islands & A cluster of gas seeps at $50-90 \mathrm{~m}$ sea depths & Possibly, deep gas & [68] \\
\hline & & 26 & & $\begin{array}{l}\text { Laptev Sea (between } 76.5^{\circ} \text { and } 77.5^{\circ} \mathrm{N} ; \\
\left.121-132^{\circ} \mathrm{E}\right)\end{array}$ & $\begin{array}{c}\text { More than } 700 \text { gas seeps, up to } 1.3 \mathrm{~km} \\
\text { in diameter }\end{array}$ & Possibly, deep gas & {$[66,69]$} \\
\hline & & 27 & & $\begin{array}{l}\text { Chukchi Sea, Herald Canyon and } \\
\text { Wrangel Island }\end{array}$ & About 90 gas seeps at $50-95 \mathrm{~m}$ sea depths & Deep gas & [70-72] \\
\hline & & 28 & & Kara Sea, near Marre-Salle polar station & $\begin{array}{l}\text { Gas seep at } 6 \mathrm{~m} \text { sea depths: } 2 \mathrm{~m} \text { in height and } \\
15 \mathrm{~m} \text { in width }\end{array}$ & Biogenic gas & [73] \\
\hline & & 29 & & Kara Sea, Universitetskaya structure & $\begin{array}{l}\text { Gas seeps from a depth of } 80 \mathrm{~m} \text { and } \\
\text { pingo-like features }\end{array}$ & Deep gas & {$[74,75]$} \\
\hline & \multirow{7}{*}{ 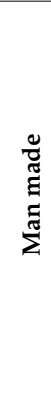 } & 30 & \multirow{7}{*}{ 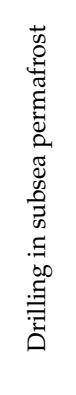 } & Pechora Sea, Kara Gates & $\begin{array}{l}10 \mathrm{~m} \text { high gas fountain from a borehole at } \\
\text { sub-bottom depth } 50 \mathrm{~m}\end{array}$ & Deep gas & {$[53,54]$} \\
\hline & & 31 & & Pechora Sea, Vaygach Island & $\begin{array}{l}10 \mathrm{~m} \text { high gas fountain from a borehole at } \\
\text { sub-bottom depth } 50 \mathrm{~m} \text {, with an ebullition zone } \\
\text { up to } 200 \mathrm{~m} \text { in diameter on the sea surface }\end{array}$ & Gas from subsea permafrost & {$[76,77]$} \\
\hline & & 32 & & Kara Sea, Baydaratskaya Bay & Gas show from sub-bottom depth $10-50 \mathrm{~m}$ & Possibly, deep gas & [78] \\
\hline & & 33 & & Kara Sea, Leningrad field & Gas show from a $200 \mathrm{~m}$ deep borehole & Possibly, deep gas & [78] \\
\hline & & 34 & & Laptev Sea, Lena Delta & Gas show from a borehole at $9 \mathrm{~m}$ depth & Gas from permafrost & [79] \\
\hline & & 35 & & Laptev Sea, Buor-Khaya Gulf & Gas show from a 13-16 m deep borehole & Gas from permafrost & [79] \\
\hline & & 36 & & Laptev Sea, Mamontov Klyk Cape & Gas show from boreholes up to $80 \mathrm{~m}$ deep & Gas from permafrost & {$[80]$} \\
\hline
\end{tabular}


$80^{\circ}$

$80^{\circ}$

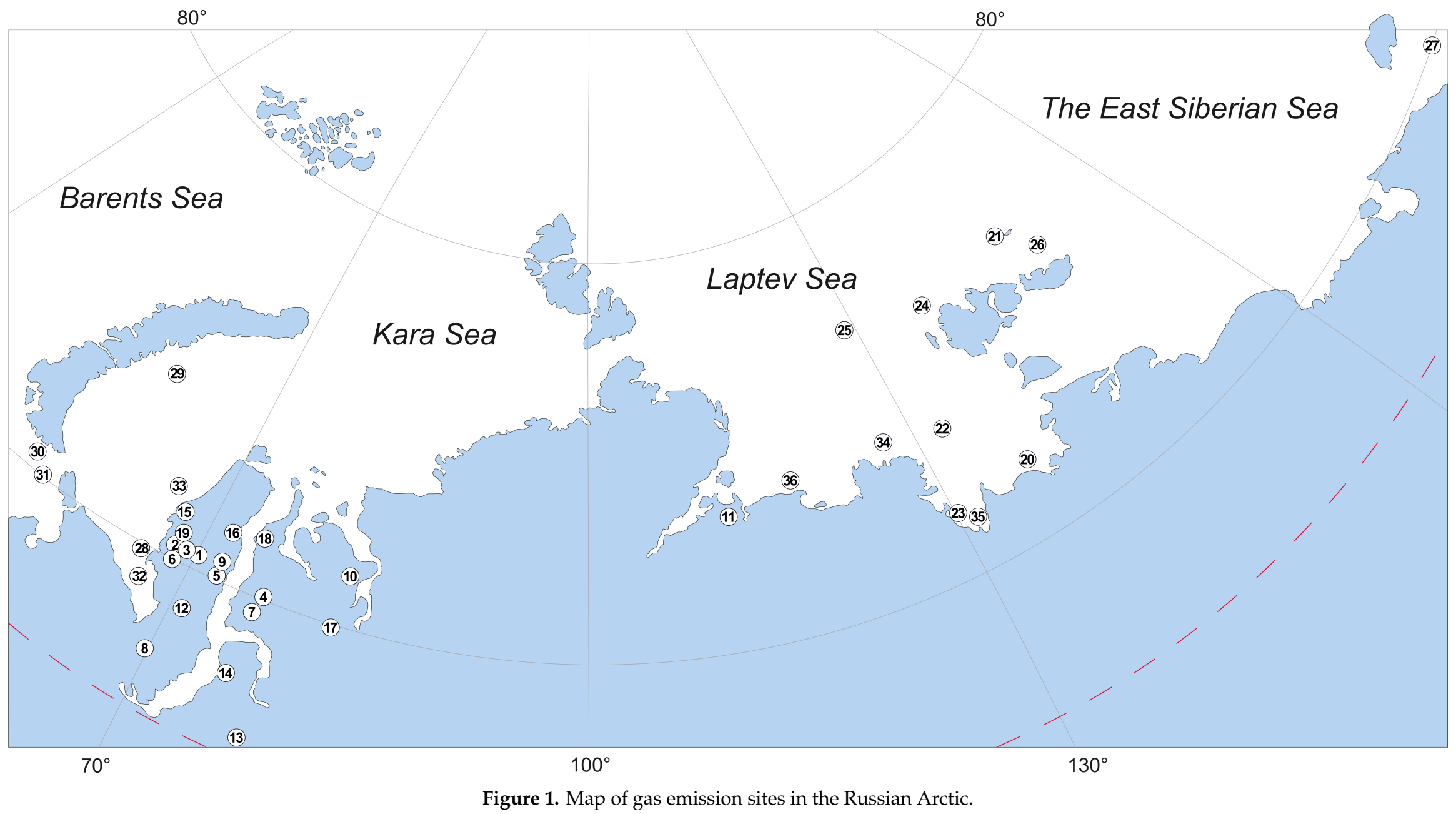




\subsection{Emission from Terrestrial Permafrost}

\subsubsection{Gas Venting from Lakes}

Gas venting from Arctic lakes was discovered in the 1950s. It can be recognized from several signatures. The most spectacular evidence appears in the blue color of water in the summertime: the so-called blue lakes that look greenish-blue from above and are transparent to a depth of 3-4 $\mathrm{m}[7,12,13]$. When these lakes were first found in the 1950s, their blue color was attributed to light reflection by bottom sediments, but became later explained by seeps or venting of deep gas that changes water chemistry. Venting of deep hydrocarbon gas through previously unknown crater-like features visible through clear water was discovered in 1971 on the bottom of a blue lake in the Urengoy gas field [81,82]. The unnamed lake was called Regin-To and became the first object of gas emission studies. The blue lakes differ from ordinary Arctic lakes that are dark due to organic matter, and their bottom is invisible below $0.5-1.0 \mathrm{~m}$ of water.

In addition to the water color, modern remote sensing methods can confirm high gas contents in Arctic lakes [10] from the presence of craters on the lake bottom, gas seeps in water, bubbles entrapped in seasonal ice, active coastal erosion, and frost heaving near the water line. Gas emission through the lake bottom can be prolonged (seeping) or blow-like (fountaining). The seeps produce a plume of dissolved gas on the lake surface while the explosions produce cone-shaped craters surrounded by parapet-like ridges of ejected material.

Most of the Arctic lakes with signatures of gas venting, which have been revealed in field campaigns and by deciphering of satellite images, are small and unnamed, and count hundreds only in the Yamal Peninsula [24]. More than half of about a thousand blue lakes mapped in West Siberia (without Yamal and Gydan Peninsulas) are located above accumulations of hydrocarbons [82]. The tabulated data (Table 1) are limited to a few largest lakes or lake systems that either have proper names or can be referenced to known geographic objects.

Satellite images (Figure 2) reveal active gas fluid dynamic processes in Lake Neyto, $\sim 17 \mathrm{~km}$ in diameter, in the central Yamal Peninsula, within the Neyto field of oil, gas, and condensate reservoirs located at least $600 \mathrm{~m}$ below the lake [10]. The images indicate day-long or possibly periodic venting of deep fluids. Active fluid emission could be seen by the color change (from light blue to dark blue; 20.07.13-30.06.16), zones of gas discharge on the bottom of the lake (dark spots; 27.06), and turbidity flows (27.06-07.07.16).

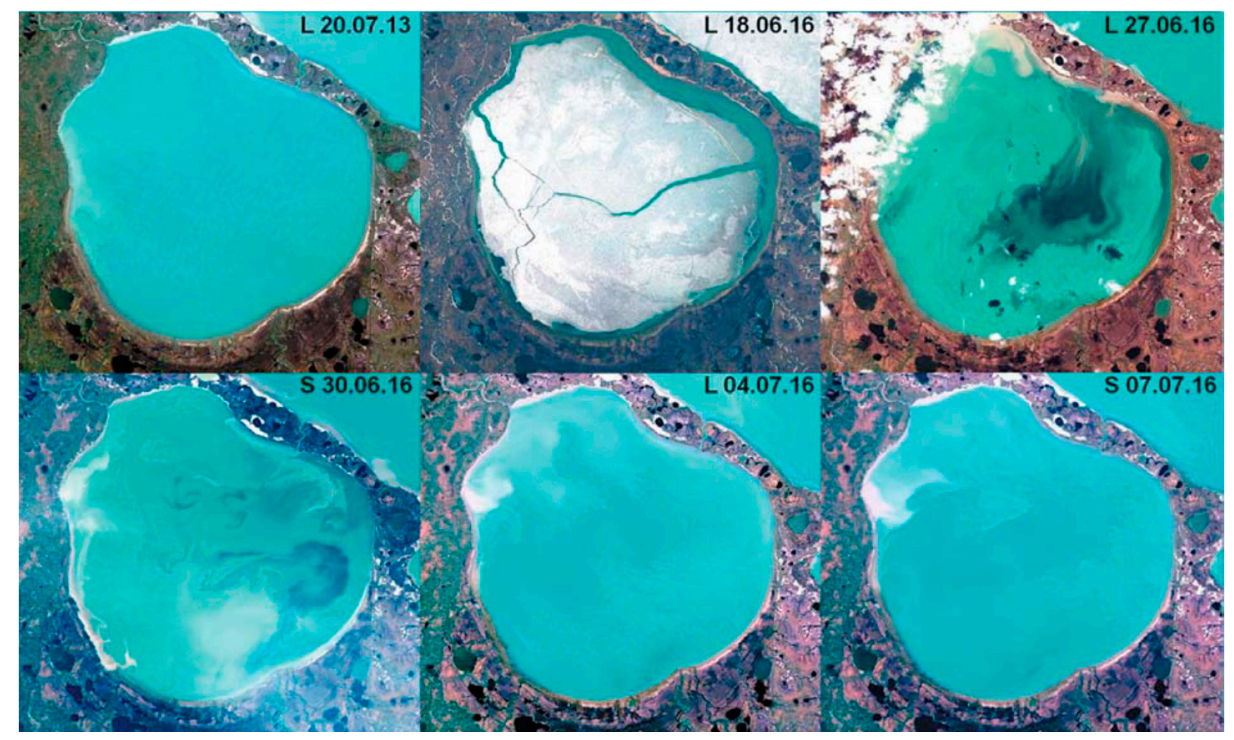

Figure 2. Remote sensing monitoring of Lake Neyto [10]. Satellite images of different dates (number on the map: 1). 
Another large lake, about $600 \mathrm{~m}$ in diameter, is located $10 \mathrm{~km}$ south of the Bovanenkovo field at $\sim 70^{\circ} \mathrm{N}$ (conventionally called Crater Lake) $[10,44]$ and is surrounded by several small and large lakes with clear water. Gas releases through a few crater-like deep vents, from 15 to $60 \mathrm{~m}$ in diameter, which are visible under the transparent lake water and must be quite deep as they look almost black against the background (image of 2009, Figure 3a). In the image of 2013, Crater Lake is turbid but the water in all surrounding lakes remains clear (Figure $3 b$ ). The turbidity may result from bottom mud that was stirred by explosive emission of gas or a water-gas mixture and was rising through a $20 \times 40 \mathrm{~m}$ vent in the southwestern lake part. Two years later, preserved rock fragments, possibly, pieces of the parapet, were detected during a helicopter survey campaign.

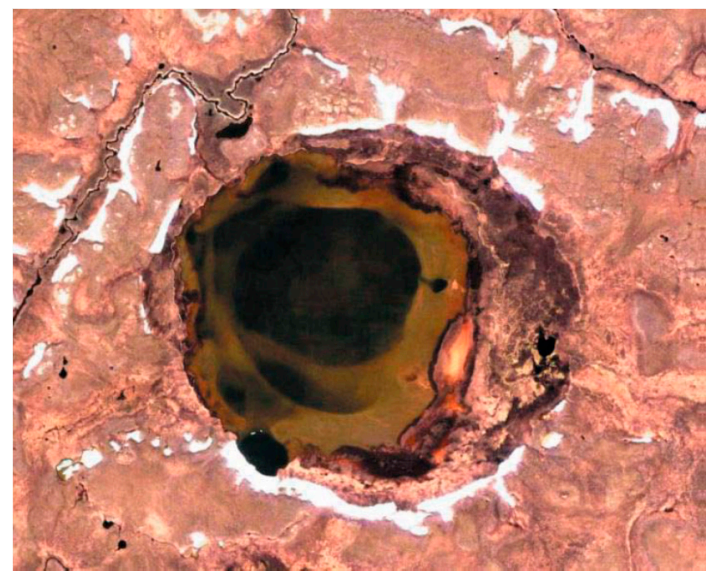

(a)

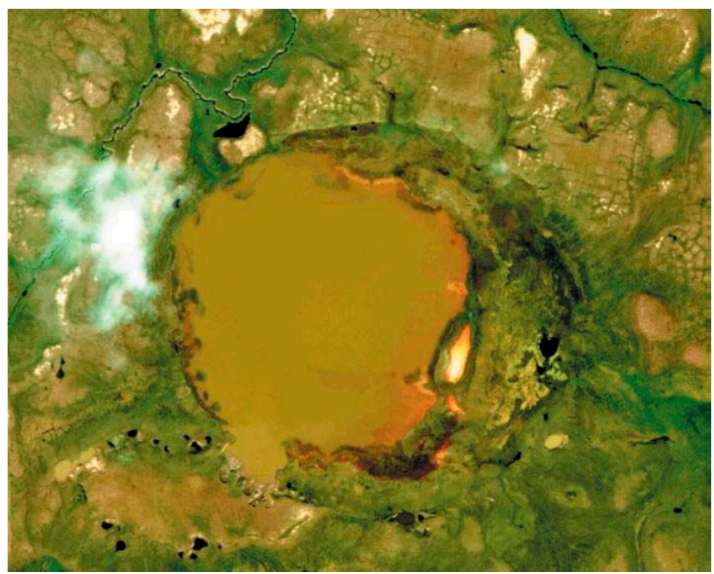

(b)

Figure 3. Satellite images of Crater Lake south of Bovanenkovo field: (a) 4 July 2009 and (b) 21 July 2013 (number on the map: 2) [10].

A group of blue lakes is known also from the central Yamal Peninsula south of the Bovanenkovo field, including several large actual (Kharangangoto, Sidya-Nadovarto, and Syakoto) and dried (Tomboyto, Ityatoraveyto, and Nyudimdato) lakes [9], with signatures of frost or thermal erosion on the shores. Lake Khalevto, the largest one in the group, is currently shrinking, as evidenced by satellite data: it was $5.2 \times 2.8 \mathrm{~km}$ in 1999 but reduced to $3.2 \times 1.4 \mathrm{~km}$ in 2013 . Active gas venting from such shrinking lakes is indicated implicitly by blue water, mudflows, and active erosion on the shores detectable in satellite images. The erosion may be due either to water temperature change (some wintertime images show holes in ice) or to the warming effect of gas, which is especially active near the shores.

A dried lake was detected in a satellite image from the central Gydan Peninsula on the left bank of the Yuribey River, $4 \mathrm{~km}$ south of Lake Merkuto [9]: a crater-like feature, $45 \mathrm{~m}$ in diameter, encircled by a parapet, is well pronounced in the lake center (Figure 4). Older images of August 2001 show that the lake was filled with water, though a cone-shaped feature already existing on the bottom. Therefore, the crater appeared before 2001 and was, possibly, associated with a long-lasting flux of gaseous fluids from beneath the lake.

Finally, gas emissions in a thermokarst lake near the Seyakha River in the Yamal Peninsula were inferred from a large hole in the ice found in March 2019. The previously unnamed lake was called Otkrytie (Russian for discovery) by Bogoyavlensky et al. [45]. Remote sensing revealed four large craters, up to 30-40 $\mathrm{m}$ in diameter, on the lake bottom, including a new crater which was the gas vent responsible for the hole. This case may represent the ascent of fluids from Cenomanian reservoirs along a permeable fault zone. Such a periodic release of gas or a gas-water mixture can produce craters. 


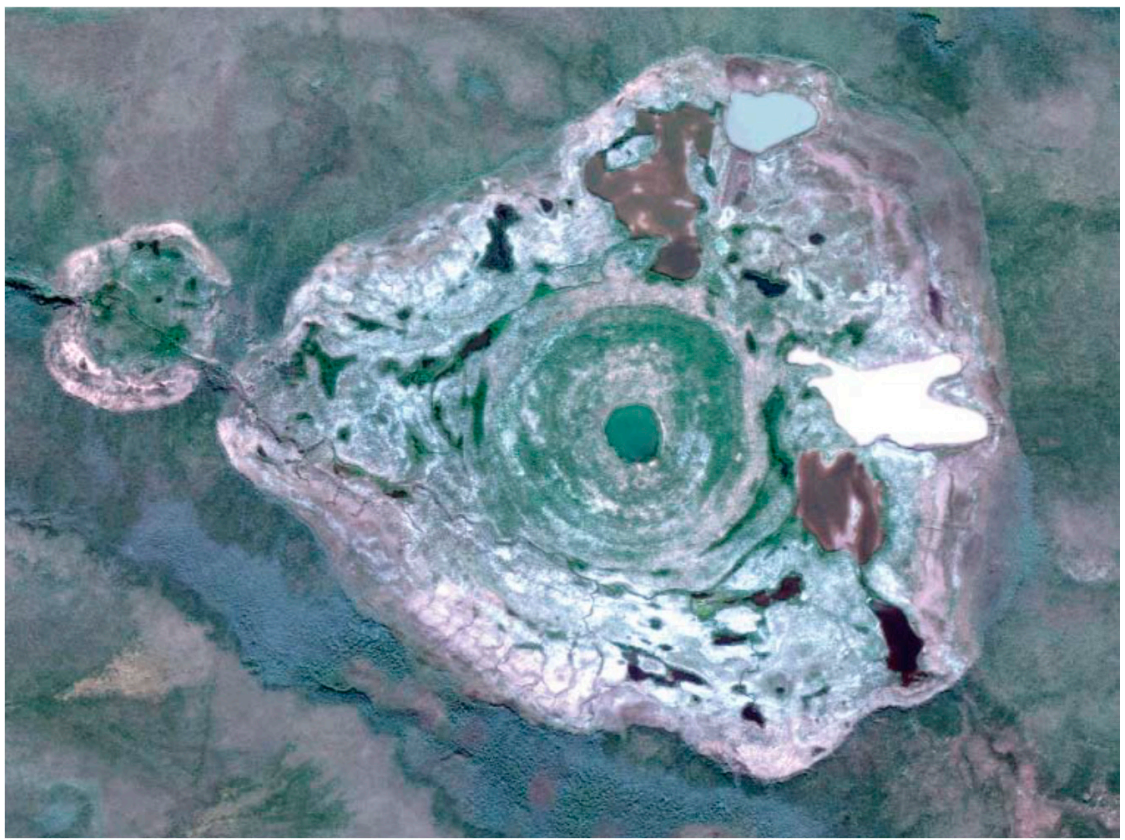

Figure 4. Dried lake with a gas emission crater in the center. Satellite image of 17 July 2013 (number on the map: 4) [9].

\subsubsection{Gas Emission with the Formation of Craters}

More than 10 gas-emission craters encircled with ridge-like parapets of ejected ground resulting from explosive events (cryovolcanism) have been found so far in the Yamal, Gydan, and Taymyr Peninsulas in northern Siberia (Table 1) [19,22,24-26]. Cryovolcanism of this kind became first known to the international scientific community in 2014, when a $70 \mathrm{~m}$ deep crater (Yamal Crater) [22,44-49] was discovered $30 \mathrm{~km}$ south of the Bovanenkovo field, $5 \mathrm{~km}$ away from the Bovanenkovo-Ukhta gas pipeline. The crater formed no earlier than in the fall of 2013 in the place of a pingo with a base diameter of $45-58 \mathrm{~m}$ and a relative height of 5-6 $\mathrm{m}$ [48]. At the time of the first field trip, the radioactivity around the crater was within the background and the methane contents measured in the crater reached 9.6-9.8\%, or slightly above the background but within the allowable maximum beyond the explosion hazard [46].

The Antipayuta gas-emission crater formed about the same time (27 September 2013) in the western Gydan Peninsula $3 \mathrm{~km}$ west of the Soletskoye gas field and $10 \mathrm{~km}$ northwest of Antipayuta Village, after which the crater was called. The crater is located on the edge of a slope in the watershed near the Yuribey River terrace, in the place of a pingo that was about $2 \mathrm{~m}$ high and $20 \mathrm{~m}$ in diameter before the explosion event. The crater has a total depth of 15-19 m, with its cone- and cylinder-shaped parts, and is remarkable by the absence of a parapet [50].

Two more gas-emission craters were found in June 2017 in the Yamal Peninsula: the Erkuta and Seyakha craters. The former was discovered in the floodplain of the Erkuta-Yakha River $220 \mathrm{~km}$ north of Salekhard and $30 \mathrm{~km}$ east of the Erkuta Science Center. People of the Center reported heaving and rupture of the previously flat surface a year before the crater discovery. The crater is located south of all other such features known in northern West Siberia [26]. When it was found, the crater had a diameter of $\sim 10-12 \mathrm{~m}$ and a depth of $20 \mathrm{~m}$ (Figure 5). The mound was destroyed only partly by the gas explosion event and left a 2-3 $\mathrm{m}$ high parapet. The carbon isotope composition of methane from ground ice in the crater wall $\left(-72 \%\right.$ o PDB $\left.\delta^{13} \mathrm{C}\right)$ indicates a biogenic origin of permafrost methane. Apart from methane, its homologs (ethane and propane) were presented in the gas samples, which demonstrates the possibility of catagenic gas participation in crater formation [26]. 


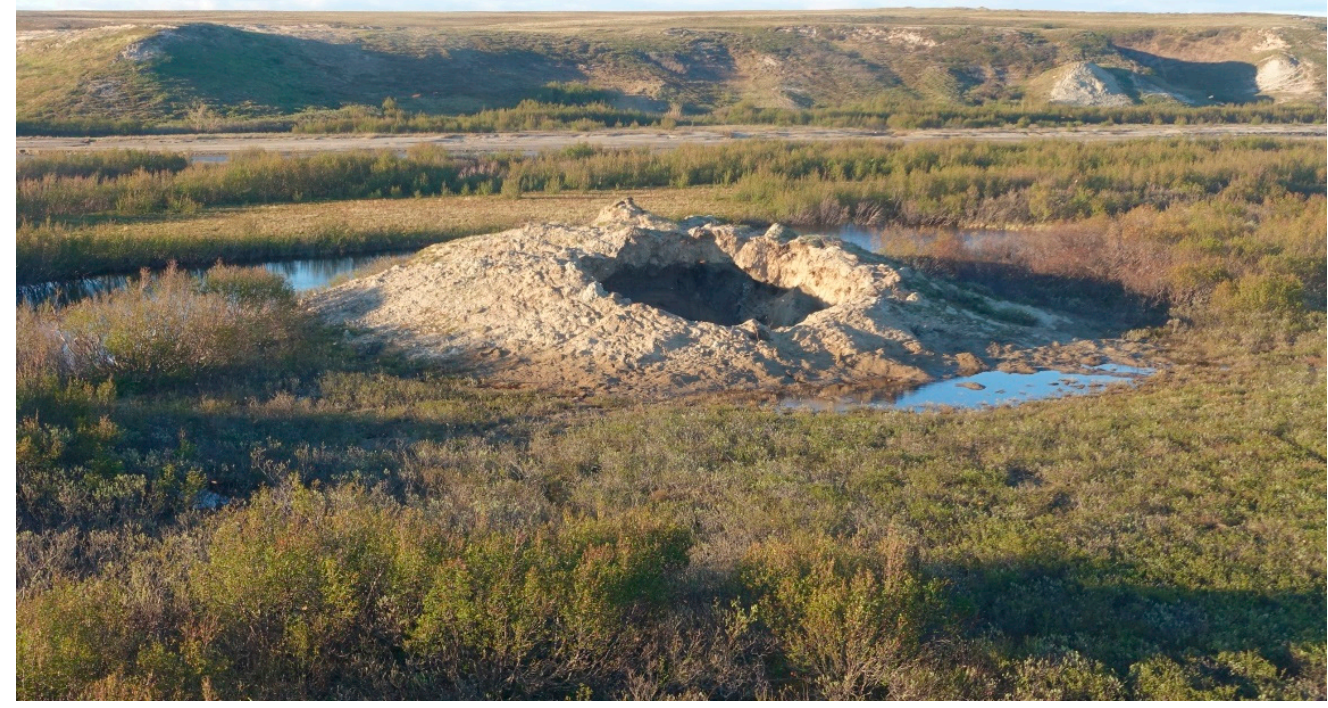

Figure 5. Gas-emission crater in the floodplain of the Erkuta-Yakha River (Yamal Peninsula), summer 2017. Photograph by A. Sinitsky (number on the map: 8).

The Seyakha crater was discovered $33 \mathrm{~km}$ north of Seyakha Village soon after an event of spontaneous ignition and explosion of gas on 28 June 2017. Gas kept burning for about 90 min and the flame reached a height of 4-5 m. The crater was located in the Myudriyakha River valley and became flooded four days after the event. It had an asymmetric shape elongated parallel to the river, was $50 \times 70 \mathrm{~m}$ in size at the water level and deeper than $50 \mathrm{~m}$. The gas vent was marked by ebullition. Analysis of gas samples revealed isotopically light predominantly methane composition with $\delta^{13} \mathrm{C}\left(\mathrm{CH}_{4}\right)=-80.6 \%$ PDB indicating biogenic origin. The ejected ground consisted of sand and clay silt permafrost and was dispersed for about $1 \mathrm{~km}$ around the epicenter. The biggest block of permafrost and ice-rich soil, which split into halves in the southwestern crater margin within the river, had an approximate size of $4 \times 8 \times 10 \mathrm{~m}$ or $100-150 \mathrm{~m}^{3}$ [24,45].

Another crater (Figure 6) was found in the eastern Gydan Peninsula by a local reindeer herder on 12 April 2013. It was located on the left bank of the Mongoche River, $10-15 \mathrm{~km}$ far from the mouth, in the southwestern coast of the Yenisey Gulf near the Deryabino gas field, $110 \mathrm{~km}$ far from Nosok Village. Fragments of permafrost and ice dispersed by the event reached sizes of $3 \times 5 \mathrm{~m}$. Like the case of the Seyakha crater, the explosion triggered gas ignition [25]. Judging by historic images, the crater formed in the place of a pingo 20-25 m in diameter. In July 2013, the crater was about 35 and $20 \mathrm{~m}$ in diameter on the outer and inner contours, respectively, according to satellite imagery, and expanded to $70 \mathrm{~m}$, with a depth of 12 to $18 \mathrm{~m}$, at the time of the summer 2014 field campaign run by the group of Epifanov (Novosibirsk). The crater was separated from a lake by a ridge composed of thawing and slumping rocks [9].

Note that some gas-emission craters in permafrost were observed only in helicopter surveys or detected in satellite images. They are, for example, the craters in the central Yamal Peninsula $20 \mathrm{~km}$ north of the Yamal Crater and $10 \mathrm{~km}$ south of the Bovanenkovo field, and one $10 \mathrm{~km}$ west of the Yamal Crater [83]. These craters have not been visited and documented yet, for different reasons, and some even remain not located, such as Osokin's crater discovered on 26.07.2013 in the Yamal Peninsula. The crater was named after the person who provided its photograph taken from a helicopter [25]. 


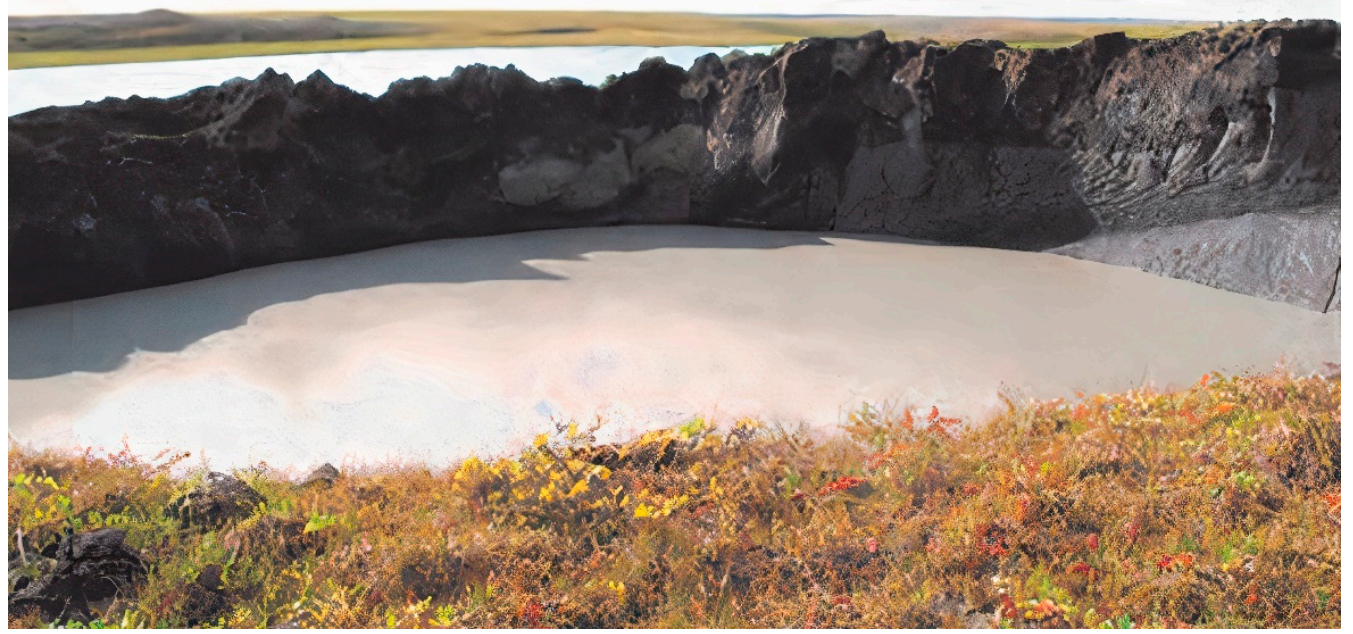

Figure 6. A crater on the left bank of the Mongoche River (Gydan Peninsula), summer 2014. Photograph by Epifanov [9] (number on the map: 10).

\subsubsection{Gas Emission Observed During Drilling in Permafrost}

Numerous gas shows were observed during drilling of geotechnical, exploration, and test boreholes in permafrost within Arctic petroleum provinces in the Yamal, Gydan, and Taz Peninsulas $[28,30-33,53,59,84-88]$. The daily gas flow rates reached tens or even hundreds of cubic meters and the emission events lasted from a few minutes to a few months [28]. The largest drilling-related gas shows were reported from the Yamal and Taz Peninsulas from depths of 40 to $130 \mathrm{~m}$ in permafrost. The first evidence of gas release from permafrost was documented in the late 1940s during petroleum exploration in the Yenisey-Khatanga basin on the left side of the Anabar River and on the Laptev Sea coast [51]. The natural gas that is released through boreholes was dominated by methane and its heavier homologs. Intrapermafrost gas from drilling depths of 70-120 $\mathrm{m}$ in the Anabar-Khatanga interfluve was venting at rates from 120 to $11,500 \mathrm{~m}^{3} / \mathrm{d}[30,51]$.

Gas release problems arose frequently during drilling campaigns of the 1980-1990s in northern West Siberia. Intense gas emissions in 1986-1990 was reported, for example, from a site along the Obskaya-Bovanenkovo railroad (Yamal Peninsula) where a rising gas flux expulsed soil and even drilling tools from 10 to $50 \mathrm{~m}$ deep geotechnical boreholes drilled across the Yuribey River. In the case of gas ignition, some gas flares kept burning for a month or longer [52,53].

Gas emission from permafrost was observed in the Zapolyarny oil-gas-condensate field in northern West Siberia (Figure 7) from 13.0 to $13.8 \mathrm{~m}$ and 14.0 to $14.5 \mathrm{~m}$ depth intervals in $\leq 20 \mathrm{~m}$ deep geotechnical boreholes. Gas that ignited at the head of one borehole was burning for about $24 \mathrm{~h}$ [89]. Furthermore, fire gas emission from 50 to $120 \mathrm{~m}$ deep intervals in permafrost occurred during drilling of exploration and production boreholes [33].

According to chemical and isotope data (Table 2) for gas sampled from gryphons in annular depressions (subsided zones of thawed permafrost) encircling the heads of producing boreholes in the Zapolyarny field, intrapermafrost gas released into unfrozen ground around the boreholes. The gas gryphons appeared as ebullition in water-filled depressions in the snow-melting spring season. 


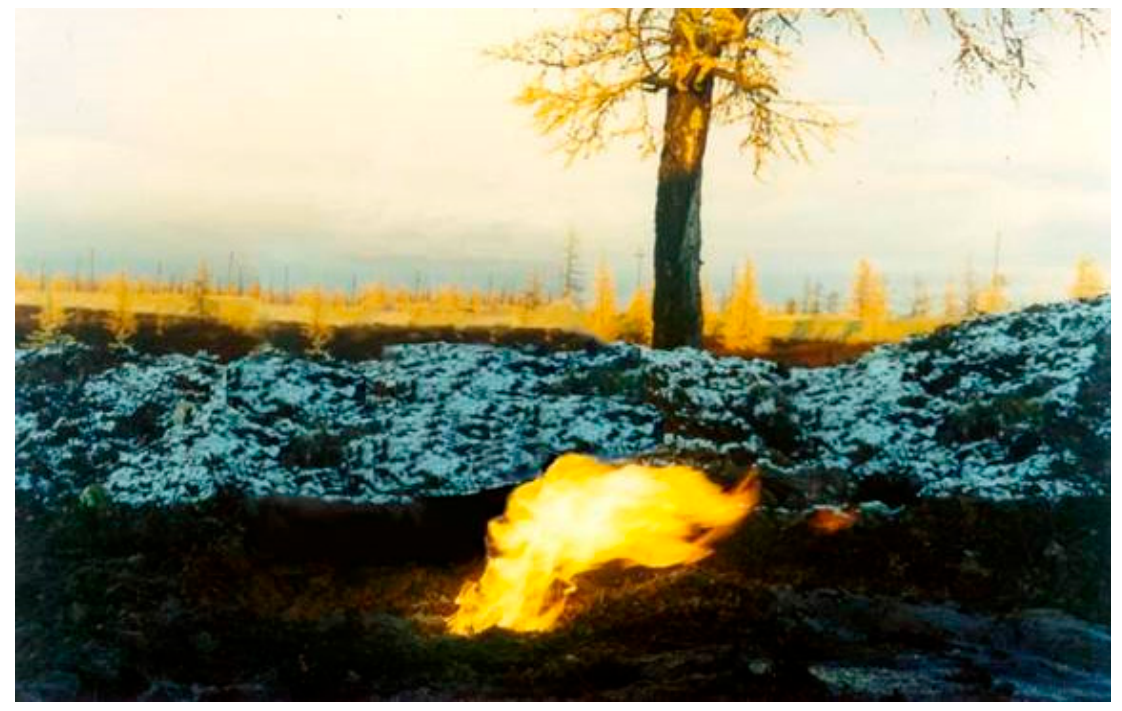

Figure 7. Burning of intrapermafrost gas rising from a depth of $15 \mathrm{~m}$ at the head of a geotechnical borehole (Zapolyarny field). Photograph by people from Fundamentproekt Company (number on the map: 13) [89].

Table 2. Gas components and $\delta^{13} \mathrm{C}$ (in methane) in gryphons around boreholes, Zapolyarny field [89].

\begin{tabular}{ccccc}
\hline \multirow{2}{*}{ Borehole No. } & \multicolumn{3}{c}{ Gas Components, \% } & \multirow{2}{*}{$\mathcal{\delta}^{\mathbf{1 3}} \mathbf{C}, \%$ \%o PDB } \\
\cline { 2 - 4 } & $\mathbf{C H}_{\mathbf{4}}$ & $\mathbf{C O}_{\mathbf{2}}$ & $\mathbf{N}_{\mathbf{2}}$ & \\
\hline 110.1 & 67.89 & 3.88 & 28.23 & -69.92 \\
110.2 & 64.63 & 5.91 & 29.46 & -69.67 \\
110.3 & 59.10 & 3.89 & 37.01 & -73.01 \\
110.4 & 41.40 & 10.45 & 48.15 & -67.97 \\
\hline
\end{tabular}

More or less long and intense gas emission from permafrost in the Yamburg oil-gas-condensate field was witnessed during exploration drilling in the 1970s from depths of 45-55 m in several boreholes [54]. Gas emission that occurred during drilling of a $53 \mathrm{~m}$ borehole in 1985 lasted for four months (the initial gas rate was 500 to $1000 \mathrm{~m}^{3} / \mathrm{d}$ ). Gas emission occurred also in annular thaw zones around operated boreholes in the course of production [30].

Other cases of active gas emission were observed during drilling of test and producing boreholes in the Kharasavey gas-condensate field at depths from 10 to $210 \mathrm{~m}$ [55,56]; South-Tambey gas-condensate field [57], from a depth interval of 40-60 m; Pelyatka gas-condensate field, at depths of 20-30 m (Figure 8); Salmanovskoye (Utrennee) oil-gas-condensate field, within 50 to $150 \mathrm{~m} \mathrm{[30].}$

The greatest amount of data on the release of intrapermafrost gas is available from the Bovanenkovo field in the Yamal Peninsula. The first gas shows were observed in the early 1980s from exploration and geotechnical boreholes, with ebullition and ejection of drilling mud in some cases [58].

Engineers of the Cryos R\&D company, which drilled more than 50 test boreholes through the whole permafrost thickness (about $200 \mathrm{~m}$ ), reported gas emission from most of the boreholes. The gas shows were widely spread in depth (from 20-30 to $130 \mathrm{~m}$ ) and laterally (Figure 9) [27,56,59]. The gas rate decayed with time, from a few days to six months [90].

According to statistical analysis, most gas emission sites in the Bovanenkovo field are located in Lower-Middle Pleistocene silt and clay silt sediments, mainly ( 67\%) at depths between 60 and $120 \mathrm{~m}$ (Figure 10a), where the gas flux reaches the highest rate of $14,000 \mathrm{~m}^{3} / \mathrm{d}$ (Figure 10b). Note that the gas rate at shallower depths $(<50 \mathrm{~m})$ does not exceed $50-150 \mathrm{~m}^{3} / \mathrm{d}[60,90]$. 




Figure 8. Methane emission from depths of 20-30 m during drilling of geotechnical boreholes in Pelyatka gas-condensate field (Gydan Peninsula, number on the map: 17).

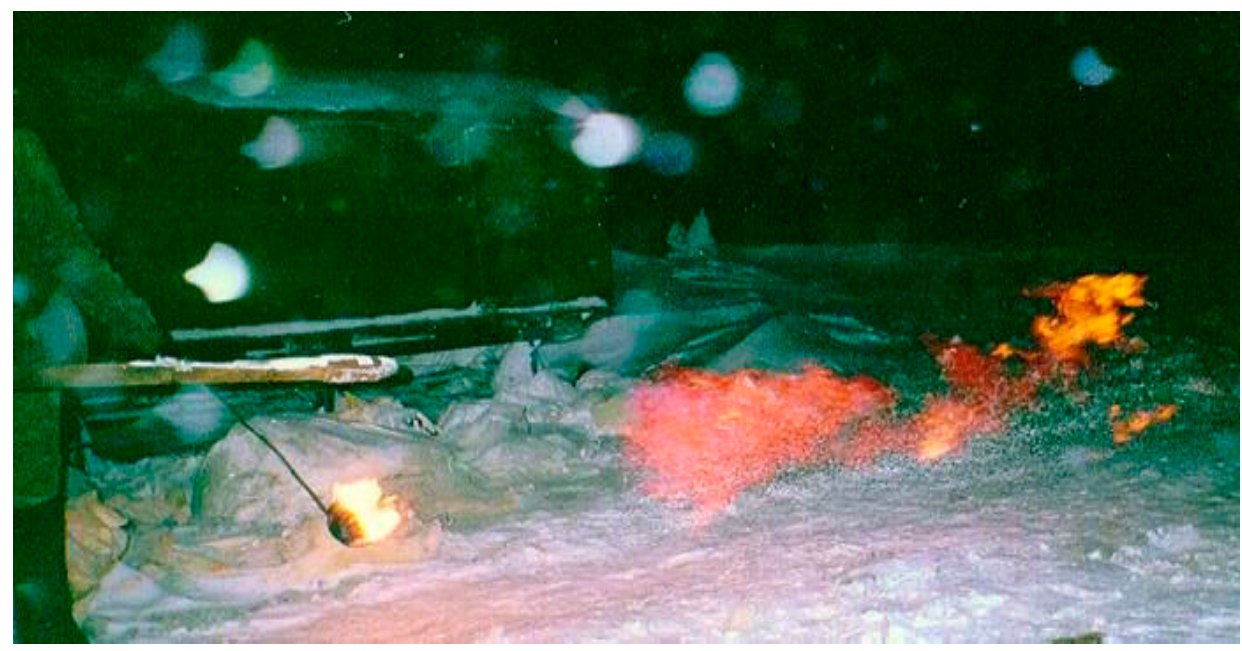

Figure 9. Release of intrapermafrost gas from a depth of $64 \mathrm{~m}$ in a test borehole. Bovanenkovo field. Photograph by Kondakov (number on the map: 19).

Almost all released natural gas was methane (98-99\%), with minor amounts of nitrogen, oxygen, carbon dioxide, and hydrogen. According to isotope analysis, methane sampled at depths from 30 to $120 \mathrm{~m}$ was of biogenic origin (-70.3 to $-74.6 \%$ PDB $\left.\delta^{13} \mathrm{C}\right)$ and differed markedly from that in the upper Cenomanian gas reservoir with $\delta^{13} \mathrm{C}$ within -46 to $-48 \%$ o $[27,28,30]$.

Thus, active gas emission observed during drilling of geotechnical and producing boreholes in many Arctic areas is due to high gas contents in shallow permafrost.

\subsection{Gas Emissions in the Arctic Shelf}

For the past three decades, gas venting was reported from onshore and offshore areas of the Arctic shelf: gas seeps and plumes, pockmarks and plow marks, as well as gas release from boreholes drilled in subsea permafrost $[2,24,36,64,79,91,92]$. 


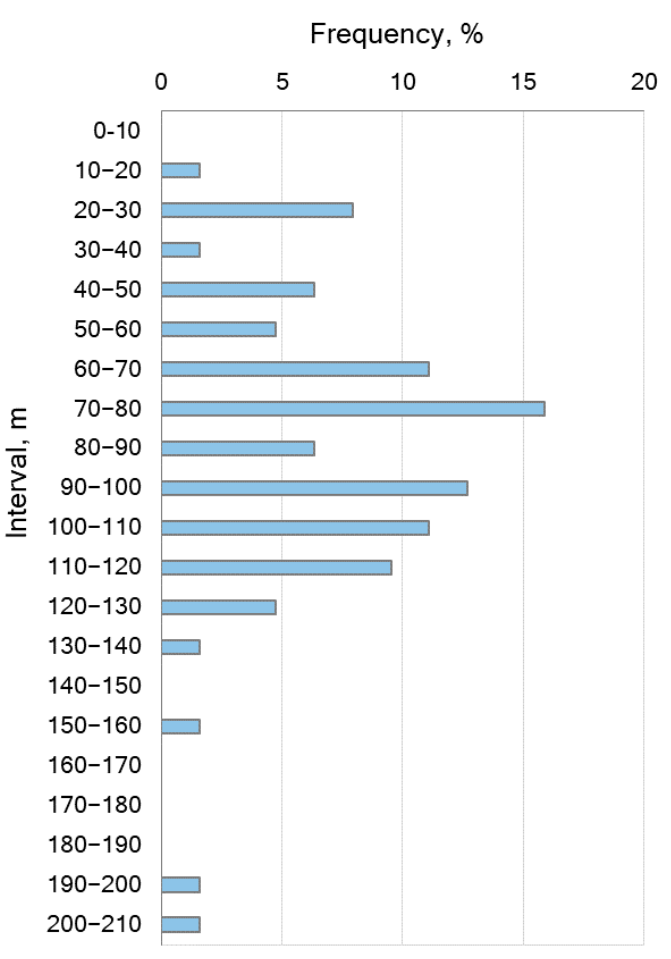

(a)

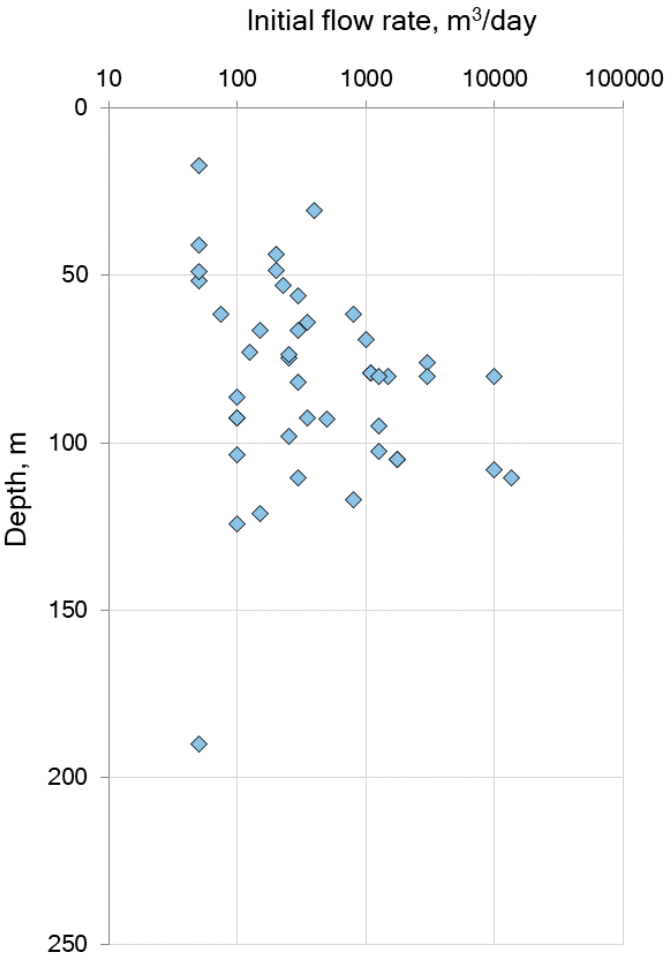

(b)

Figure 10. Frequency, as the number of gas shows, per $10 \mathrm{~m}$ depth interval (a) and initial flow rate (b) of gas in permafrost within the Bovanenkovo field.

\subsubsection{Natural Gas Emission}

Gas venting from the bottom of the Laptev Sea was observed in the Lena Delta in the 1960s, locally as intense ebullition [61]. Chemical analysis of the emitted gas with gas impurities from the atmosphere revealed 39\% $\mathrm{CH}_{4}$ (and its heavier homologs) and 7.4\% $\mathrm{CO}_{2}[53,61]$. Possibly, in this area, the emission of deep catagenic gases mixed with atmospheric air occurred, which can be concluded based on the presence of components of deep origin (ethane, propane, hydrogen, argon, and helium) in the gas composition [30].

A wealth of data on methane venting in the eastern Russian Arctic sector (Laptev, East Siberian, and Chukchi Seas) was collected in the late 20th to early 21st century: seeps and plumes of methane from the bottom and anomalous contents of dissolved methane in seawater, often attributed to the degradation of subsea permafrost with the formation of taliks [35,91].

Several large gas plumes were found in the 1970-1980s near Bennett Island on the East Siberian shelf, and one was more than $300 \mathrm{~km}$ long and $10 \mathrm{~km}$ wide. Retrospective analysis of satellite images revealed multiple gas emission events in the area: at least 150 events between 1973 and 1986 [62] and in later years as well, e.g., a gas plume of $1000 \mathrm{~km}$ in length and $25 \mathrm{~km}$ in width detectable in satellite images of 2008 [10]. Note that the Skoltech research team, with the participation of a member of our team (B.A.B.), found anomalous methane concentrations neither in water nor in air around the Island in October 2019 during a cruise of R/V Akademik Mstislav Keldysh, though several large gas seeps appeared over an area of $12 \mathrm{~m}^{2}$ in the central East Siberian shelf at a sea depth of $45-47 \mathrm{~m}$. According to onboard chemical analyses, the gas was pure methane (99.9\%), and its content in air was 6-9 times the background: 16 ppm against 2 ppm, respectively [93,94] (Figure 11). 


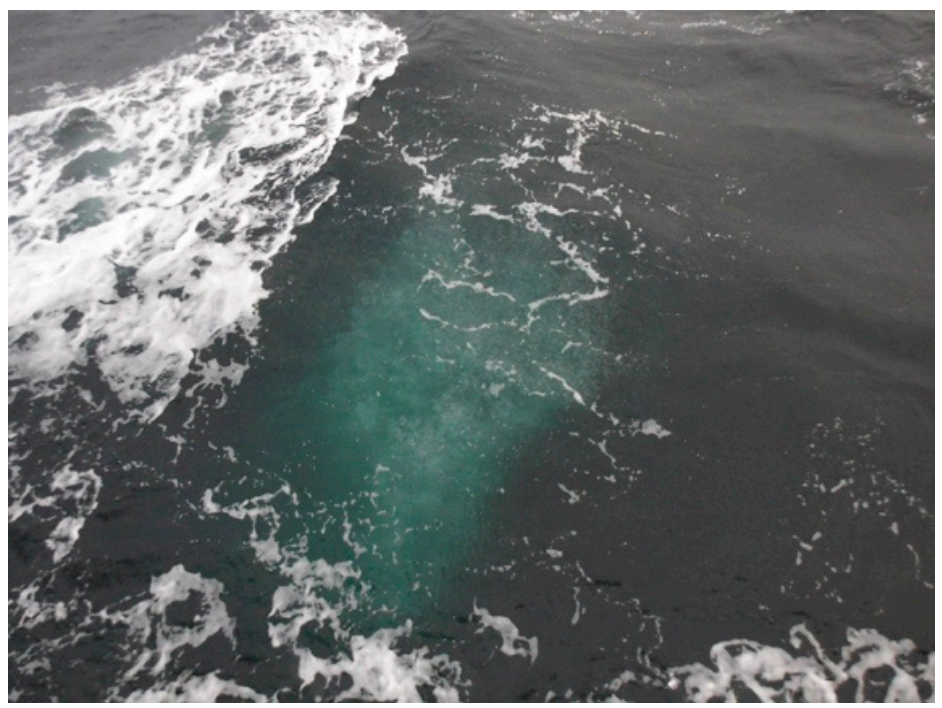

Figure 11. Gas seeps on the East Siberian shelf. Photograph by Bukhanov, October 2019.

In September 2004, gas seeps were observed between Semyonovsky Island and Lena Delta in the Laptev Sea [63]. The area, extended to Ivashkina Lagoon (between $71^{\circ}$ and $74^{\circ} \mathrm{N}$ and $129^{\circ}$ and $\left.131^{\circ} \mathrm{E}\right)$ was explored later [64], and the concentration of methane in the air was found to exceed significantly the background $\left(\sim 5 \times 10^{2} \mathrm{nM}\right)$. Additional studies by the same team in October 2013 and monitoring over the whole of 2015 revealed anomalously high methane fluxes to the atmosphere (5 to $24 \mathrm{mg} \mathrm{CH} / \mathrm{m}^{2} / \mathrm{d}$ in October 2013 and $\sim 35 \mathrm{mg} \mathrm{CH} / \mathrm{m}^{2} / \mathrm{d}$ during 2014), as well as 17 seeps of different intensities in the shallow Ivashkina Lagoon at a sea depth within $4 \mathrm{~m}[65,66]$.

A large gas seep was discovered by chance at a sea depth of $60 \mathrm{~m}$ in the central Laptev Sea, northwest of Kotelny Island, during a cruise of R/V Viktor Buinitsky in 2007 [67]. A year later, in 2008, a group of researchers found more than one hundred seeps, with up to $4 \mathrm{~mm}$ gas bubbles in water, during a cruise of R/V Yakov Smirnitsky in the Laptev shelf, in the area of New Siberian Islands at a sea depth of 50-90 $\mathrm{m}[68,91]$.

Studies in 2011-2012 [66,69] in another area of the Laptev Sea (between $76.5^{\circ}$ and $77.5^{\circ} \mathrm{N}$ and $121^{\circ}$ and $132^{\circ} \mathrm{E}$ ) revealed more than 700 seeps of presumably deep gas at a water depth of 50-160 m, including some large ones reaching 1000-1300 $\mathrm{m}$ in diameter, with bubbles from 1 to $10 \mathrm{~mm}$.

Methane venting in the Laptev Sea and East Siberian shelf areas can be inferred from high concentrations of methane in near-surface water: $10-15 \mathrm{nM}$ or locally more than $100 \mathrm{nM}$ recorded on the shelf of Great Lyakhovsky Island northeast of the Lena Delta and in the Laptev Strait (up to $138 \mathrm{nM}$ ); methane anomalies were also measured in air above Great Lyakhovsky Island [36]. Gas apparently releases all year round, judging by the ubiquitous presence of methane bubbles entrapped within the sea ice (recovered from boreholes of $\sim 0.3 \mathrm{~m}$ average diameter) [36].

About 90 gas seeps were discovered in the Herald Canyon and around Wrangel Island on the Chukchi shelf in 2014 during a cruise as part of a joint German-Russian-American project [70]. The seeps occurred on the relatively flat shelf part at a sea depth of 50 to $95 \mathrm{~m}$. Zones of intense gas emission, with 4-6 $\mathrm{mm}$ bubbles, were detectable in processed acoustic images (Figure 12).

In addition, in Chukchi sea high concentrations (with a maximum for methane of $34.6 \mathrm{~cm}^{3} / \mathrm{kg}$ and for its homologs: ethane, propane, butan, $0.02 \mathrm{~cm}^{3} / \mathrm{kg}$ ) were registered. Gas seepage sites occur at water depths of $40-80 \mathrm{~m}$ and the intensity of methane fluxes at the sediment-water interface within the southern and northern sites was estimated to be 14.5 and $0.7 \mathrm{nmol} \mathrm{dm}^{-2} \mathrm{~d}^{-1}$, respectively [71,72].

On the Kara Sea shelf, near Western Yamal, in 2012 during the expedition of the R/V Neotrazimy under the direction of VNIIOkeangeologiya, numerous gas seeps were observed at a sea depth of about $20 \mathrm{~m}$, some of which rose up to 20-25 m above sea level. At the same time, the concentrations of dissolved methane were measured. The analysis of the results showed a high concentration of 
methane equal to the results of a previous expedition in 2010, which demonstrates the continuity of gas flows over an area of about $7500 \mathrm{~km}^{2}$. One of the large gas seeps, $2 \mathrm{~m}$ in height and $15 \mathrm{~m}$ in width, was detected at a distance of $1.5 \mathrm{~km}$ from the coastline near the Marre-Salle polar station at a water depth of $6 \mathrm{~m}$. In addition, a gas plume with a length of 30-60 km was recorded, extending from the isobath $20 \mathrm{~m}$ to a water depth of $>40 \mathrm{~m}$, pertaining to insular permafrost [73].

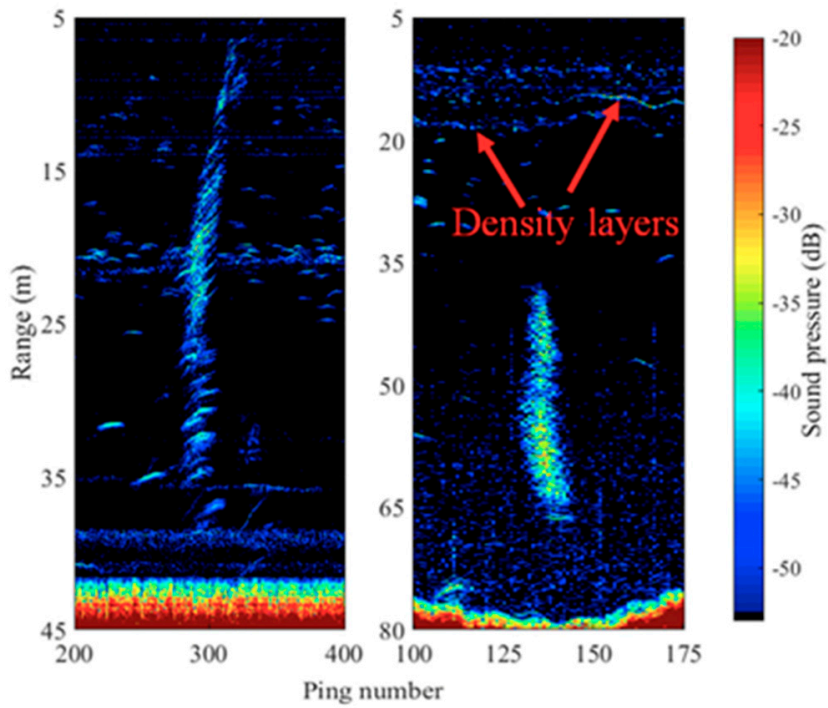

Figure 12. Acoustic anomalies associated with gas seeps in Herald Canyon (Chukchi Sea, number on the map: 27) [70].

Later, a team of VNIIOkeangeologiya (St. Petersburg), while cruising on R/V Aldan in 2013 [74], discovered several seeps in the Kara shelf (Universitetskaya structure) at a sea depth of $\sim 80 \mathrm{~m}$, as well as typical pingo-like features rising 30-40 $\mathrm{m}$ above the sea bottom (Figure 13).

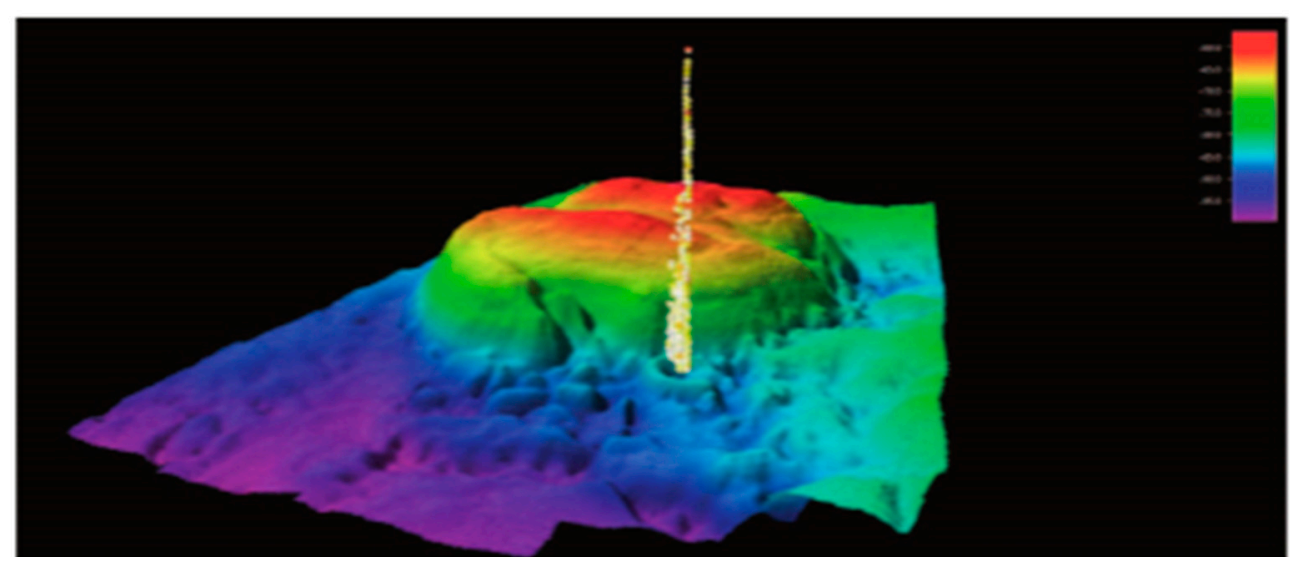

Figure 13. A 3D image of a gas plume and a pingo, Universitetskaya structure, Kara Sea shelf (number on the map: 29) [74].

The existence of gas emissions can be inferred implicitly from pockmarks and plow marks found locally in the Chukchi, Kara, and Barents Seas [95]. They are abundant in the Barents Sea, at a depth of $300 \mathrm{~m}$, within the Shtokman gas-condensate field [96-99]. Some plow marks are kilometers long, 100-200 m wide, and 5-10 m deep [92]. Additionally, large plow marks with a high methane concentration in bottom sediments were observed in the Pechora Sea at a water depth of 50-100 m (up to $600 \mathrm{~m}$ in diameter and $25 \mathrm{~m}$ in height) and in the South Kara sea at a water depth of 35-45 m (up to $1000 \mathrm{~m}$ in diameter and $10 \mathrm{~m}$ in height) [6]. Small plow marks (5 m deep and $30 \mathrm{~m}$ wide) were detected by acoustic soundings in the Ob Bay (Kara Sea), though some reached widths of 100-200 m [100]. 


\subsubsection{Man-Induced Gas Emission}

Some gas release events in the Arctic shelf have anthropogenic causes associated with drilling operations. It occurs when drilling taps gas-bearing sediments and gas pockets and may trigger various kinds of emergency: ejection of drilling fluid and soil, ignition, equipment shut down, etc.

A violent gas explosion was reported from the Pechora shelf in the Kara Strait area $[53,54]$ where offshore drilling under $64 \mathrm{~m}$ of water stripped paleopermafrost in a sand formation at $22 \mathrm{~m}$ below the bottom. Gas released from a clay layer beneath the paleopermafrost at a sub-bottom depth of $50 \mathrm{~m}$ rose in a fountain $10 \mathrm{~m}$ above the vessel deck. The explosion was followed by ebullition within $8 \mathrm{~m}$ around and expanded to $100 \mathrm{~m}$ in a few minutes. Bubbles disappeared in a few hours but echo sounding four and ten days after the event detected a high gas fountain more than $10 \mathrm{~m}$ in diameter rising $40 \mathrm{~m}$ above the bottom. Core samples from the $\leq 50 \mathrm{~m}$ sub-bottom depth contained about $70 \%$ of freshwater ice which cracked upon the core recovery, possibly as a result of gas hydrate dissociation caused by pressure and temperature changes [53,54].

Before that event, in 1995, more than fifty 10-25 m high submarine pingo-like features were discovered in the Pechora Sea west of Vaygach Island $\left(69.97^{\circ} \mathrm{N} ; 57.45^{\circ} \mathrm{E}\right)$ at a sea depth of $50 \mathrm{~m}$. Four geotechnical boreholes in the area stripped permafrost at the $20 \mathrm{~m}$ sub-bottom depth and one hole tapped a zone of overpressure and released a pressurized gas-water mixture at $50 \mathrm{~m}$ below the bottom in ice-rich sediments filling a depression between pingoes. The gas fountain rose $10 \mathrm{~m}$ or higher above the sea surface and was surrounded by a 150-200 m ebullition zone. Drilling was stopped because of the emergency, while progressively decaying gas venting continued for more than ten days [76,77].

Drilling-related gas emission was observed also at several pipelining sites in the Kara Sea: Baydarata Bay, Ob Bay, and Taz Estuary, at 10 to $50 \mathrm{~m}$ sub-bottom depths [78]. An explosive emission event during drilling in 1990 within the Leningrad gas field destroyed the borehole head and formed a crater (200 m hole bottom depth; sea depth $<100 \mathrm{~m}$ ) [78].

A few cases are known from the Laptev Sea. One event, 30 min long, occurred in 2016 during drilling in the Lena Delta (near Samoylovsky Island research station) at 7-9 m sub-bottom depths. Another case was reported from the Buor-Khaya Gulf, where a $20-40 \mathrm{~cm}$ high gas flare, blue on the top, appeared during drilling to depths of 13-16 m and kept burning for $30 \mathrm{~min}$. Air samples from the borehole head showed up to $45 \%$ of methane [79]. In 2005 gas ignited at a head of an $80 \mathrm{~m}$ deep borehole during heating of the coring tube in the western Laptev Sea near Cape Mamontov Klyk. Gas was burning for $10 \mathrm{~min}$ and had a visible height decreasing from $30-40 \mathrm{~cm}$ to $10-20 \mathrm{~cm}$ [80].

\section{Discussion}

The suggested inventory of the available data on gas emissions in the Russian Arctic collected for about 50 years follows a previous overview by Are of 1998 [53] which summarized the evidence available at that time. Are [53] characterized the forms and signatures of gas fluid venting in different areas of the Arctic controlled by the specificity of the gas sources. We provide more recent evidence and present the data in a table and in a map (Table 1; Figure 1), arranged according to the location of emission sites (in lakes, on the land, or on the shelf), with the indication of specific signatures and possible sources of gas. This synthesis can provide a basis for the prediction of natural and man-caused gas release hazards for areas of observed methane emissions in the Arctic region.

Gas venting from Arctic lakes has the following signatures (for the described major cases, without considering ongoing methane generation in lake sediments):

- Greenish-blue transparent water, often with a visible lake bottom;

- Craters and similar features on the lake bottom;

- More or less strongly eroded parapet or rock fragments around craters as evidence of explosive emission;

- Mudflows in clear water associated with the release of a gas-water mixture through muddy bottom sediments; 
- Ebullition;

- Bubbles of various shapes entrapped in ice;

- Ice holes persistent over the winter season, through which gas fluids vent to the air.

The review of published evidence on deep gas-emission craters (Figure 1), along with our field and laboratory data [26], allows a number of inferences:

- In the witnessed cases, gas release was accompanied by explosions and fire;

- All gas analyses showed the presence of methane;

- Many of the gas-emission events were preceded by heaving that produced meters high mounds;

- All discovered craters were round in shape but differed in size and depth, up to tens of m;

- In all cases, rocks around the craters contained ground or pore ice evident in the crater walls or in the ejected fragments;

- Most of the craters were encircled by parapets of ejected rock and soil; rock fragments were dispersed to distances of $100 \mathrm{~m}$ or farther around;

- Most of the craters became filled with water and transformed into lakes in two or three years after the emission event.

Gas release from geotechnical or producing boreholes in the Arctic region (especially in northern West Siberia) has the following common features:

- Gas most often releases from shallow permafrost at depths from 10-20 m to $150 \mathrm{~m}$;

- Gas flux ranges from seeping to explosions at rates of hundreds to thousands of $\mathrm{m}^{3} / \mathrm{d}$;

- Gas emission can last from a few minutes to a month or longer;

- Most of the emission events are known from oil and gas fields in northern West Siberia (Yamal, Taz, and Gydan Peninsulas);

- Gas released from rocks of different lithologies, but most often from sandy-loam and sandy horizons with low salinity;

- Gas emission occurs from ice-rich permafrost;

- Gas mostly consists of methane and smaller amounts of nitrogen and carbon dioxide;

- The carbon isotope composition of gas indicates its biogenic origin ( -65 to $-75 \%$ o PDB $\delta^{13} \mathrm{C}$ );

- Intrapermafrost gas can exist in a free or hydrate form; the presence of free gas is limited by the amount of pore ice while gas hydrates can remain stable within a certain range of pressures and temperatures (hydrate stability zone); metastable relict hydrates that formed under favorable conditions in the past can survive due to self-preservation $[33,85,101,102]$.

The available data on gas emissions in the Russian Arctic shelf show that

- High methane concentrations in surface waters of the Arctic shelf may have different causes, among which degradation of subsea permafrost, dissociation of intra- or subpermafrost gas hydrates, and formation of gas-permeable taliks [3,5,38,73];

- Methane in most of the gas seeps is of deep-seated (thermogenic) origin;

- Water column transfer of methane occurs by diffusive and ebullition mechanisms; gas migration in bubbles produces seeps and plumes; gas vents to the atmosphere if bubbles reach sizes at least 3-4 mm;

- Gas emission can arise when drilling strips intra- or subpermafrost gas accumulations or can result from the destabilization of gas hydrates;

- Pockmarks or plow marks are implicit indicators of gas venting on the Arctic shelf.

\section{Conclusions}

We have synthesized the available extensive published evidence on gas emissions in the continental and shelf areas of the Russian Arctic and presented the data in a table and in a map (Table 1; Figure 1). 
The table shows the location, signatures, and possible sources of gas emission, with reference to relevant publications. Gas emission can be natural or anthropogenic; natural venting is possible in lakes and can be explosive, with the formation of craters. The characterized natural gas emission events have implications for gas transport mechanisms in terrestrial and subsea permafrost. Anthropogenic emission cases, which are most often related to drilling, differ in stripping depth of the gas-saturated permafrost, as well as in characteristics and duration of events.

Although the tabulated and mapped gas emission data are limited to the most active, large, and well-documented cases, the overview provides an idea of the extent and main trends of the process.

Author Contributions: Conceptualization, methodology, supervision, E.C.; writing manuscript and editing, E.C., N.S., D.D., V.E. and B.B. All authors have read and agreed to the published version of the manuscript.

Funding: The research was supported by the Russian Science Foundation (Grant No. 18-77-10063).

Conflicts of Interest: The authors declare no conflict of interest.

\section{References}

1. Shakhova, N.; Semiletov, I.; Chuvilin, E. Understanding the permafrost-hydrate system and associated methane releases in the East Siberian Arctic Shelf. Geosciences 2019, 9, 251. [CrossRef]

2. Sergienko, V.I.; Lobkovskii, L.I.; Semiletov, I.P.; Dudarev, O.V.; Dmitrievskii, N.N.; Shakhova, N.E.; Romanovskii, N.N.; Kosmach, D.A.; Nikol'skii, D.N.; Nikiforov, S.L.; et al. The Degradation of Submarine Permafrost and the Destruction of Hydrates on the Shelf of East Arctic Seas as a Potential Cause of the Methane Catastrophe: Some Results of Integrated Studies in 2011. Dokl. Earth Sci. 2012, 446, 1132-1137. [CrossRef]

3. Romanovskii, N.N.; Hubberten, H.-W.; Gavrilov, A.V.; Eliseeva, A.A.; Tipenko, G.S. Offshore Permafrost and Gas Hydrate Stability Zone on the Shelf of East Siberian Seas. Geo-Marine Lett. 2005, 25, 167-182. [CrossRef]

4. Dean, J.F.; Middelburg, J.J.; Röckmann, T.; Aerts, R.; Blauw, L.G.; Egger, M.; Jetten, M.S.M.; de Jong, A.E.E.; Meisel, O.H.; Rasigraf, O.; et al. Methane feedbacks to the global climate system in a warmer world. Rev. Geophys. 2018, 56, 207-250. [CrossRef]

5. Semenov, P.; Portnov, A.; Krylov, A.; Egorov, A.; Vanshtein, B. Geochemical Evidence for Seabed Fluid Flow Linked to the Subsea Permafrost Outer Border in the South Kara Sea. Chemie Erde 2019, 125509. [CrossRef]

6. Serov, P.; Portnov, A.; Mienert, J.; Semenov, P.; Ilatovskaya, P. Methane Release from Pingo-like Features across the South Kara Sea Shelf, an Area of Thawing Offshore Permafrost. J. Geophys. Res. F Earth Surf. 2015, 120, 1515-1529. [CrossRef]

7. Kuzin, I.L.; Lyubina, Y.N.; Reinin, I.V. Gas production in West Siberian lakes and its relation to oil and gas fields. In Tectonic Criteria for Petroleum Exploration (Remote-Sensing Evidence); VNIGRI: Leningrad, Russia, 1990; pp. 117-127. (In Russian)

8. Glotov, V.E.; Glotova, L.P. Natural sources of atmospheric methane in Circumpacific region of cryolithozone (North-East of Russia). Bull. Samara Sci. Center Russ. Acad. Sci. 2015, 17, $26-32$.

9. Sizov, O.V. Remote sensing of gas emission consequences in northern West Siberia. Geomatika 2015, 1, 53-68.

10. Bogoyavlensky, V.I.; Sizov, O.S.; Mazharov, A.V.; Bogoyavlensky, I.V.; Nikonov, R.A. Remote sensing of terrestrial gas emission in the Arctic: Yamal Peninsula. Arkt. Ekol. Ekon. 2016, 3, 4-15.

11. Streletskaya, I.D.; Vasiliev, A.A.; Oblogov, G.E.; Streletskiy, D.A. Methane content in ground ice and sediments of the Kara Sea coast. Geosciences 2018, 8, 434. [CrossRef]

12. Kuzin, I.L. On the priority in the studies of land gas shows in Western Siberia. Sov. Geol. Geophys. 1990, 31, 142-144.

13. Kuzin, I.L. On the nature of anomalous lakes: Indicators of hydrocarbons in deep sediments. In Assessment of Reservoir Petroleum Potential in West Siberia; VNIGRI: St. Petersburg, Russia, 1992; pp. 129-137. (In Russian)

14. Kuzin, I.L. The extent of natural gas emission in West Siberia. Izvestiya RGO 1999, 131, $24-35$.

15. Rivkin, F.M. Gas contents in shallow permafrost. In Geocryological Conditions of the Kharasavey and Krusenstern Gas Condensate Fields (Yamal Peninsula); VNIIEgeosystem: Moscow, Russia, 2003; pp. 133-146. (In Russian)

16. Desyatkin, A.R.; Fedorov, P.P.; Nikolaev, A.N.; Borisov, B.Z.; Desyatkin, R.V. Methane emission during floods in thermokarst lakes of Central Yakutia. Vestnik NEFU 2016, 2, 5-14. 
17. Badu, Y.B. Gas shows and the nature of cryolithogenesis in marine sediments of the Yamal Peninsula. Earth Cryosphere 2017, XXI, 42-54. [CrossRef]

18. Savichev, A.; Leibman, M.; Kadnikov, V.; Kallistova, A.; Pimenov, N.; Ravin, N.; Dvornikov, Y.; Khomutov, A. Microbiological study of Yamal lakes: A key to understanding the evolution of gas emission craters. Geosciences 2018, 8, 478. [CrossRef]

19. Dvornikov, Y.A.; Leibman, M.O.; Khomutov, A.V.; Kizyakov, A.I.; Semenov, P.B.; Bussmann, I.; Babkin, E.M.; Heim, B.; Portnov, A.; Babkina, E.A.; et al. Gas-Emission craters of the Yamal and Gydan peninsulas: A proposed mechanism for lake genesis and development of permafrost landscapes. Permafr. Periglac. Process. 2019, 30, 146-162. [CrossRef]

20. Vlasov, A.N.; Khimenkov, A.N.; Volkov-Bogorodskiy, D.B.; Levin, Y.K. Natural explosive processes in permafrost. Dostizheniya Nauki Tekhniki 2017, 3, 41-56. [CrossRef]

21. Kizyakov, A.; Khomutov, A.; Zimin, M.; Khairullin, R.; Babkina, E.; Dvornikov, Y.; Leibman, M. Microrelief associated with gas emission craters: Remote-sensing and field-based study. Remote Sens. 2018, 10, 677. [CrossRef]

22. Buldovicz, S.N.; Khilimonyuk, V.Z.; Bychkov, A.Y.; Ospennikov, E.N.; Vorobyev, S.A.; Gunar, A.Y.; Gorshkov, E.I.; Chuvilin, E.M.; Cherbunina, M.Y.; Kotov, P.I.; et al. Cryovolcanism on the earth: Origin of a spectacular crater in the Yamal Peninsula (Russia). Sci. Rep. 2018, 8, 13534. [CrossRef]

23. Vorobyev, S.; Bychkov, A.; Khilimonyuk, V.; Buldovicz, S.; Ospennikov, E.; Chuvilin, E. Formation of the Yamal crater in northern West Siberia: Evidence from geochemistry. Geosciences 2019, 9, 515. [CrossRef]

24. Bogoyavlensky, V.I.; Bogoyavlensky, I.V.; Sizov, O.S.; Nikonov, R.A.; Kargina, T.N. Earth degassing in the Arctic: Comprehensive studies of the distribution of frost mounds and thermokarst lakes with gas blowout craters on the Yamal peninsula. Arct. Ecol. Econ. 2019, 4, 52-68. [CrossRef]

25. Khimenkov, A.N.; Sergeev, D.O.; Vlasov, A.N.; Volkov-Bogorodsky, D.B. Explosive processes in the permafrost zone as a new type of geocryological hazard. Geoecology. Eng. Geol. Hydrogeol. Geocryol. 2019, 6, 30-41. [CrossRef]

26. Chuvilin, E.; Stanilovskaya, J.; Titovsky, A.; Sinitsky, A.; Sokolova, N.; Bukhanov, B.; Spasennykh, M.; Cheremisin, A.; Grebenkin, S.; Davletshina, D.; et al. A Gas-Emission Crater in the Erkuta River Valley, Yamal Peninsula: Characteristics and Potential Formation Model. Geosciences 2020, 10, 170. [CrossRef]

27. Chuvilin, E.M.; Yakushev, V.S.; Perlova, E.V.; Kondakov, V.V. Gas component of permafrost within the Bovanenkovo gas condensate field (Yamal Peninsula). Doklady Earth Sci. 1999, 369, 522-524.

28. Yakushev, V.S.; Chuvilin, E.M. Natural gas and gas hydrate accumulations within permafrost in Russia. Cold Reg. Sci. Technol. 2000, 31, 189-197.

29. Bondarev, V.L.; Mirotvorskiy, M.Y.; Zvereva, V.B.; Oblekov, G.I.; Shaydullin, R.M.; Gudzenko, V.T. Above-Cenomanian sediments in the Yamal Peninsula: Gas contents and chemical compositions (a case study of the Bovanenkovo oil-and-gas-condensate field). Geol. Geofiz. Razrab. Neftyanykh Gazov. Mestorozhdenii 2008, 5, 22-34.

30. Yakushev, V.S. Natural Gas and Gas Hydrates in Permafrost; VNIIGAZ: Moscow, Russia, 2009; 192p, ISBN 978-5-89754-048-8. (In Russian)

31. Kraev, G.; Schulze, E.-D.; Kholodov, A.; Chuvilin, E.; Rivkina, E. Cryogenic displacement and accumulation of biogenic methane in frozen soils. Atmosphere 2017, 8, 105. [CrossRef]

32. Kraev, G.; Rivkina, E.; Vishnivetskaya, T.; Belonosov, A.; van Huissteden, J.; Kholodov, A.; Smirnov, A.; Kudryavtsev, A.; Tshebaeva, K.; Zamolodchikov, D. Methane in gas shows from boreholes in epigenetic permafrost of Siberian Arctic. Geosciences 2019, 9, 67. [CrossRef]

33. Chuvilin, E.; Bukhanov, B.; Davletshina, D.; Grebenkin, S.; Istomin, V. Dissociation and self-preservation of gas hydrates in permafrost. Geosciences 2018, 8, 431. [CrossRef]

34. Obzhirov, A.; Shakirov, R.; Salyuk, A.; Suess, E.; Biebow, N.; Salomatin, A. relations between methane venting, geological structure and seismo-tectonics in the Okhotsk sea. Geo-Marine Lett. 2004, 24, 135-139. [CrossRef]

35. Shakhova, N.; Semiletov, I.; Leifer, I.; Salyuk, A.; Rekant, P.; Kosmach, D. Geochemical and geophysical evidence of methane release over the East Siberian Arctic Shelf. J. Geophys. Res. Oceans 2010, 115, C08007. [CrossRef]

36. Shakhova, N.; Semiletov, I.; Salyuk, A.; Yusupov, V.; Kosmach, D.; Gustafsson, Ö. Extensive methane venting to the atmosphere from sediments of the East Siberian Arctic Shelf. Science 2010, 327, 1246-1250. [CrossRef] [PubMed] 
37. Burwicz, E.; Rüpke, L.; Wallmann, K. Estimation of the global amount of submarine gas hydrates formed via microbial methane formation based on numerical reaction-transport modeling and a novel parameterization of Holocene sedimentation. Geochim. Cosmochim. Acta 2011, 75, 4562-4576. [CrossRef]

38. Romanovskii, N.N.; Eliseeva, A.A.; Gavrilov, A.V.; Tipenko, G.S.; Hubberten, X. The long-term dynamics of the permafrost and gas hydrate stability zone on rifts of the East Siberian Arctic shelf ((Report 2). Kriosf. Zemli 2006, 10, 29-38.

39. Anisimov, O.A.; Borzenkova, I.I.; Lavrov, S.A.; Strelchenko, Y.G. The current dynamics of the submarine permafrost and methane emission on the shelf of the eastern arctic seas. Ice Snow 2012, 52, 97-105. [CrossRef]

40. Anisimov, O.A.; Zaboikina, Y.G.; Kokorev, V.A.; Yurganov, L.N. Possible causes of methane release from the East Arctic seas shelf. Ice Snow 2014, 54, 69-81. [CrossRef]

41. Kim, Y.-G.; Kim, S.; Lee, D.-H.; Lee, Y.M.; Kim, H.J.; Kang, S.-G.; Jin, Y.K. Occurrence of Active Gas Hydrate Mounds in the Southwestern Slope of the Chukchi Plateau, Arctic Ocean. Episodes 2020, 43, 811-823. [CrossRef]

42. Paull, C.K.; Ussler, W.; Dallimore, S.R.; Blasco, S.M.; Lorenson, T.D.; Melling, H.; McLaughlin, F.A. Origin of pingo-like features on the Beaufort Sea shelf and their possible relationship to decomposing methane gas hydrates. Geophys. Res. Lett. 2007, 34. [CrossRef]

43. Rajan, A.; Mienert, J.; Bünz, S. Acoustic evidence for a gas migration and release system in Arctic glaciated continental margins offshore NW-Svalbard. Mar. Pet. Geol. 2012, 32, 36-49. [CrossRef]

44. Bogoyavlensky, V.I. Oil and gas shows on land and offshore areas of the Arctic and the world ocean. Bureniye i Neft' 2015, 6, 4-10. Available online: https://burneft.ru/archive/issues/2015-06/4 (accessed on 22 September 2020).

45. Bogoyavlensky, V.I.; Erokhin, G.N.; Nikonov, R.A.; Bogoyavlensky, I.V.; Bryksin, V.M. Study of catastrophic gas blowout zones in the Arctic based on passive microseismic monitoring (on the example of Lake Otkrytiye). Arctic Ecol. Econ. 2020, 1, 93-104. [CrossRef]

46. Leibman, M.O.; Plekhanov, A.V. Yamal gas emission crater: Results of preliminary survey. KholodOk 2014, 2, 9-15.

47. Leibman, M.O.; Kizyakov, A.I.; Plekhanov, A.V.; Streletskaya, I.D. New permafrost feature-Deep crater in Central Yamal, West Siberia, Russia, as a response to local climate fluctuations. Geogr. Environ. Sustain. 2014, 7, 68-80. [CrossRef]

48. Kizyakov, A.I.; Sonyushkin, A.V.; Leibman, M.O.; Zimin, M.V. Geomorphological conditions of the gas-emission crater and its dynamics in central Yamal. Earth's Cryosphere 2015, 19, 15-25.

49. Olenchenko, V.V.; Sinitsky, A.I.; Antonov, E.Y.; Eltsov, I.N.; Kushnarenko, O.N.; Plotnikov, A.E.; Potapov, V.V.; Epov, M.I. Results of geophysical researches of the area of new geological formation "Yamal crater". Earth's Cryosphere 2015, 19, 94-106.

50. Kizyakov, A.I.; Zimin, M.V.; Sonyushkin, A.V.; Dvornikov, Y.A.; Khomutov, A.V.; Leibman, M.O. Comparison of gas emission crater geomorphodynamics on Yamal and Gydan peninsulas (Russia), based on repeat very-high-resolution stereopairs. Remote Sens. (Basel) 2017, 9, 1023. [CrossRef]

51. Kalinko, M.K. Geological History and Petroleum Potential of the Khataigekoy Basin; Gostoptekhizdat: Leningrad, Russia, 1959; 358p. (In Russian)

52. Mamzelev, A.P.; Are, F.E. Geological-engineering conditions of Yamal peninsula along designing railroad. In Proceedings of the 6th International Conference on Permafrost, Beijing, China, 5-9 July 1993; South China University of Technology Press: Guangzhou China, 1993; Volume 1, pp. 436-442.

53. Are, F.E. Emission of deep gas into the atmosphere. Kriosfera Zemli 1998, II, 42-50.

54. Melnikov, P.I.; Melnikov, V.P.; Tsarev, V.P.; Degtiarev, B.V.; Mizulina, N.B.; Popov, A.P.; Berezniakov, A.I.; Svetchnikov, A.M. Generation of hydrocarbons in the permafrost. Izv. AN SSSR Ser. Geol. 1989, 2, 118-128. (In Russian)

55. Badu, Y.B. The cryolithic structure of the ground. In The Cryosphere of Petroleum Fields, Yamal Peninsula: In 3 volumes. Vol. 1. The Kharasavey Field; Nedra: St. Petersburg, Russia, 2006; pp. 85-111. (In Russian)

56. Chuvilin, E.M.; Perlova, E.V.; Baranov, Y.B.; Kondakov, V.V.; Osokin, A.B.; Yakushev, V.S. Structure and Properties of Permafrost in the Southern Bovanenkovo Gas-Condensate Field; GEOS: Moscow, Russia, 2007; 137p. (In Russian) 
57. Kondakov, V.V.; Kusova, O.F.; Kondakov, M.V. Geocryological conditions of the northeastern Yamal Peninsula. In Proceedings of the IV Conference of Russian Permafrost Scientists, Moscow, Russia, 7-9 June 2011; University Book: Moscow, Russia, 2011; pp. 89-94. (In Russian).

58. Bolshakov, Y.Y.; Kultikov, A.M. Analysis of gas emission while drilling in the Bovanenkovo and Kharasavey fields. In Transactions, Institute of North Development Problems, Siberian Branch of the USSR Academy of Sciences; Institute of North Development Problems: Tyumen, Russia, 1989; 74p, N2 16-88. (In Russian)

59. Kondakov, V.V.; Galyavich, A.S. Comprehensive studies of permafrost sediments with an assessment of their water and gas saturation. In Proceedings of the Problems of Cryology of the Earth: Abstracts. Conf., Pushchino, Russia, 20-24 April 1998.

60. Chuvilin, E.M.; Yakushev, V.S.; Perlova, E.V. Gas and gas hydrates in the permafrost of Bovanenkovo gas field, Yamal Peninsula, West Siberia. Polarforschung 2000, 68, 215-219.

61. Ivanov, M.S. Modern permafrost coastal Deltaic sediments of the Yana basin. Voprosy Geografii Yakutii 1969, 5, 138-147.

62. Masurenkov, Y.P.; Slezin, Y.B.; Sobisevich, A.L. Gas plumes near the Bennett island. Izvestiya RAN Sr. Geogr. 2015, 3, 86-95. (In Russian) [CrossRef]

63. Rekant, P.V.; Tumskaya, V.E.; Gusev, E.A.; Schwenk, T.; Spiess, F.; Cherkashev, G.A.; Kassens, H. Distribution and features of subsea permafrost in the Semenovskaya and Vasilievskaya banks (Laptev Sea), from seismoacoustic profiling data. In Laptev Sea and Adjacent Arctic Seas: Current State and History; Moscow State University: Moscow, Russia, 2009; pp. 292-308. ISBN 9785211057166. (In Russian)

64. Shakhova, N.E.; Semiletov, I.P.; Salyuk, A.N.; Belcheva, N.N.; Kosmach, D.A. Methane anomalies in the near-water atmospheric layer above the shelf of the East Siberian Arctic Sea. Doklady Earth Sci. 2007, 415, 764-768. [CrossRef]

65. Shakhova, N.; Semiletov, I.; Leifer, I.; Sergienko, V.; Salyuk, A.; Kosmach, D.; Chernykh, D.; Stubbs, C.; Nicolsky, D.; Tumskoy, V.; et al. Ebullition and storm-induced methane release from the East Siberian Arctic Shelf. Nat. Geosci. 2014, 7, 64-70. [CrossRef]

66. Shakhova, N.; Semiletov, I.; Sergienko, V.; Lobkovsky, L.; Yusupov, V.; Salyuk, A.; Salomatin, A.; Chernykh, D.; Kosmach, D.; Panteleev, G.; et al. The East Siberian Arctic Shelf: Towards further assessment of permafrost-related methane fluxes and role of sea ice. Philos. Trans. R. Soc. 2015, 373, 2014045. [CrossRef] [PubMed]

67. Shakhova, N.E.; Sergienko, V.I.; Semiletov, I.P. The contribution of the East Siberian Shelf to the modern methane cycle. Her. Russ. Acad. Sci. 2009, 79, 237-246. [CrossRef]

68. Baranov, B.; Galkin, S.; Vedenin, A.; Dozorova, K.; Gebruk, A.; Flint, M. Methane seeps on the outer shelf of the Laptev Sea: Characteristic features, structural control, and benthic fauna. Geo-Marine Lett. 2020, 40, 541-557. [CrossRef]

69. Samarkin, V.; Semiletov, I.P.; Finke, N.; Shakhova, N.E.; Joye, S.B. Methane carbon stable isotope signatures in waters and sediments of the Laptev Sea Shelf. In Proceedings of the American Geophysical Union Fall Meeting, San Francisco, CA, USA, 3-7 December 2012; p. B21D-0411.

70. Weidner, E.; Weber, T.C.; Mayer, L.; Jakobsson, M.; Chernykh, D.; Semiletov, I. A wideband acoustic method for direct assessment of bubble-mediated methane flux. Cont. Shelf Res. 2019, 173, 104-115. [CrossRef]

71. Matveeva, T.; Savvichev, A.S.; Semenova, A.; Logvina, E.; Kolesnik, A.N.; Bosin, A.A. Source, Origin, and Spatial Distribution of Shallow Sediment Methane in the Chukchi Sea. Oceanography 2015, 28, 202-217. [CrossRef]

72. Matveeva, T.V.; Semenova, A.A.; Shchur, N.A.; Logvina, E.A.; Nazarova, O.V. Prospects of Gas Hydrate Presence in the Chukchi Sea. J. Min. Inst. 2017, 226, 387-396. [CrossRef]

73. Portnov, A.; Smith, A.J.; Mienert, J.; Cherkashov, G.; Rekant, P.; Semenov, P.; Serov, P.; Vanshtein, B. Offshore Permafrost Decay and Massive Seabed Methane Escape in Water Depths $>20 \mathrm{~m}$ at the South Kara Sea Shelf. Geophys. Res. Lett. 2013, 40, 3962-3967. [CrossRef]

74. Firsov, Y.G.; Ivanov, M.V.; Koloskov, E.N. A new stage in bathymetric studies of the Russian Arctic waters: A case study of the Kara Sea. Bull. Admiral Makarov State Univ. Mar. River Fleet 2014, 6, 115-124. (In Russian)

75. Koloskov, E.N.; Firsov, Y.G. The use of modern hydrographic technologies for the study of bottom topography and gas occurrence in the Russian Arctic seas. Bull. Admiral Makarov State Univ. Mar. River Fleet 2015, 3, 54-62. (In Russian) 
76. Bondarev, V.N.; Rokos, S.I.; Kostin, D.A.; Dlugach, A.G.; Polyakova, N.A. Underpermafrost accumulations of gas in the upper part of the sedimentary cover of the Pechora Sea. Russ. Geol. Geophys. 2002, 43, 545-556.

77. Rokos, S.I. Engineering-geological features of shallow overpressure zones in reservoirs of the Pechora and southern Kara shelf. Inzhenernaya Geol. 2008, 4, 22-28.

78. Bogoyavlensky, V.I. Natural and technogenic threats in fossil fuels production in the Earth's cryolithosphere. Russ. Min. Ind. 2020, 1, 97-118. [CrossRef]

79. Grigoriev, M.N. Permafrost degradation East Siberian Arctic seas: Evidence from field campaigns of 2014-2016. Probl. Arktiki Antarkt. 2018, 1, 89-96.

80. Safronov, A.F.; Shits, E.Y.; Grigor'ev, M.N.; Semenov, M.E. Formation of gas hydrate deposits in the Siberian Arctic Shelf. Russ. Geol. Geophys. 2010, 51, 83-87. [CrossRef]

81. Kruglikov, N.M.; Kuzin, I.L. Deep gas shows in the Urengoy gas field. Trans. ZapSibNIGNI 1973, 37, $96-106$. (In Russian)

82. Kuzin, I.L. Blue lakes in humid areas. Izvestiya RGO 2001, 133, 44-57.

83. Bogoyavlensky, V.I.; Bogoyavlensky, I.V.; Nikonov, R.A. Results of aerial, space and field invetigations of large gas blowouts near Bovanenkovo field on Yamal Peninsula. Arctic Ecol. Econ. 2017, 3, 4-17. [CrossRef]

84. Cherskiy, N.V.; Tsarev, V.P. Prospects for petroleum development. In Improvement of Subsoil Use in the Northern and Eastern USSR, Part 1; Cherskiy, N.V., Ed.; YaB SB AS USSR: Yakutsk, Russia, 1973; pp. 54-60. (In Russian)

85. Yakushev, V.S.; Perlova, E.V.; Makhonina, N.A.; Chuvilin, E.M.; Kozlova, E.V. Gas hydrates in deposits on continents and islands. Ross. Khimicheskiy Zhurnal 2003, 3, 80-90.

86. Yakushev, V.S.; Istomin, V.A. Gas-hydrates self-preservation effect. In Physics and Chemistry of Ice; Maeno, N., Hondoh, T., Eds.; Hokkaido University Press: Sapporo, Japan, 1992; pp. 136-139.

87. Yakutseni, V.P. Unconventional resources of natural hydrocarbons-An additional raw material reserve of the national economy of the USSR. In Resources of Unconventional Gas Raw Materials and Problems of Its Development, Proceedings of the VNIGRI; Yakutseni, V.P., Ed.; VINIGRI: Leningrad, Russia, 1990; 261p. (In Russian)

88. Avetov, N.P.; Krasnova, E.A.; Yakushev, V.S. Possible causes and nature of gas emission around gas and gas condensate boreholes in the Yamburg oil and gas condensate field. Vesti Gazovoy Nauki 2018, 1, 33-40.

89. Makhonina, N.A.; Perlova, E.V.; Yakushev, V.S.; Akhmedsafin, S.K. Permafrost gas accumulations in the Zapolyarnoye oil-gas-condensate field. Nauka Tekhnika Gazov. Promyshlennosti 2004, 1-2, 43-46.

90. Skorobogatov, V.A.; Yakushev, V.S.; Chuvilin, E.M. Sources of natural gas within permafrost north-west Siberia. In Proceedings of the Seventh International Conference on Permafrost. Collection Nordicana, N57, Yellowknife, NT, Canada, 23-27 June 1998; pp. 1001-1007.

91. Yusupov, V.I.; Salyuk, A.N.; Karnaukh, V.N.; Semiletov, I.P.; Shakhova, N.E. Detection of methane ebullition in shelf waters of the Laptev sea in the Eastern Arctic region. Doklady Earth Sci. 2010, 430, 261-264. [CrossRef]

92. Bondur, V.G.; Kuznetsova, T.V.; Vorobyev, V.E.; Zamshin, V.V. Remote sensing detection of gas shows (gas seeps) on the Russian shelf. Georesursy Geoenergiya Geopolit. 2014, 1, 1-23. Available online: http: //oilgasjournal.ru/vol_9/bondur.html (accessed on 22 September 2020).

93. Luhn, A. Russian Scientists Find "Most Powerful" Ever Methane Seep in Arctic Ocean; The Telegraph: Moscow, Russia, 2019.

94. Nikiforov, S. Scientists Have Discovered Extremely Large Methane Emission in the East Siberian Sea; Bull. Tomsk Polytechnical University: Tomsk, Russia, 2019.

95. Ivanov, G.I. Methodology and Results of Ecogeochemical Investigations of Barents Sea; VNIIOkeangeologiya: Saint Petersburg, Russia, 2002; p. 153, ISBN 5-88994-059-7. (In Russian)

96. Mayer, L.A.; Brumley, K.; Andronikov, A.; Chayes, D.N.; Armstrong, A.A.; Calder, B.; Hall, J.K.; Clyde, W.C.; Bothner, W.A.; Gardner, J.V. Recent Mapping and Sampling on Chukchi Borderland and the Alpha/Mendeleev Ridge Complex. In Proceedings of the American Geophysical Union Fall Meeting, San Francisco, CA, USA, 15-19 December 2008; p. C11C-0516.

97. Judd, A.; Hovland, M. Seabed Fluid Flow: The Impact on Geology, Biology, and the Marine Environment; Cambridge University Press: Cambridge, UK, 2007; pp. 1-475, ISBN 9780511535918. [CrossRef]

98. Lastochkin, A.N.; Naryshkin, G.D. New understanding of the Arctic sea bottom topography. Okeanologiya 1989, 29, 968-973.

99. Vinogradov, V.A.; Gusev, E.A.; Lopatin, B.G. Age and structure of sediments in the Eastern Russian Arctic shelf. Geol. -Geofizicheskiye Kharakteristiki Lithosfery Arkticheskogo Regiona 2004, 5, 202-212. 
100. Bogoyavlensky, V.I. Prospects and problems of petroleum production in the Arctic Shelf. Bureniye i Neft' 2012, 11, 4-9.

101. Yershov, E.D.; Lebedenko, Y.P.; Chuvilin, E.M.; Istomin, V.A.; Yakushev, V.S. Features of gas hydrate occurrence in permafrost. Dokl. USSR Acad. Sci. 1991, 321, 788-791.

102. Dallimore, S.R.; Chuvilin, E.M.; Yakushev, V.S. Field and laboratory characterization of intrapermafrost gas hydrates, Mackenzie Delta, N.W.T., Canada. In Proceedings of the 2nd International Conference on Natural Gas Hydrates, Toulouse, France, 24-29 June 1996; pp. 525-531.

(C) 2020 by the authors. Licensee MDPI, Basel, Switzerland. This article is an open access article distributed under the terms and conditions of the Creative Commons Attribution (CC BY) license (http://creativecommons.org/licenses/by/4.0/). 